\title{
Determining the Level of Predicting Teachers' Competitive Attitudes by Educational Beliefs
}

\author{
Hakkı KAHVECi $^{\text {a* }}$ (ORCID ID - 0000-0002-8578-5622) \\ ${ }^{a}$ Eskişehir Osmangazi Üniversitesi, Eğitim Fakültesi, Eskişehir/Türkiye
}

\section{Article Info}

DOI: $10.14812 /$ cufej.934187

Article history:

Revised 28.10.21

Accepted 29.10.21

Keywords:

Teacher,

Competitiveness,

Educational beliefs,

Philosophy of education
Received 07.05.21

\begin{abstract}
In this study, determining the prediction level of competitive attitudes of teachers' educational beliefs was aimed. For this purpose, The Teacher Competitiveness Scale was developed for teachers. In the process of developing the scale, exploratory factor analysis, reliability analysis and confirmatory factor analysis were performed on two different samples. In the analysis, it was observed that the scale consists of 4 subdimensions called winning by competition, approval, superiority and exclusion and 16 items. As the second scale, The Educational Beliefs Scale consisting of 40 items and 5 dimensions was used. In the second sample, independent groups t test, correlation analysis and multiple regression analysis were performed. Analyses showed that male teachers had significantly higher scores compared with female teachers according to the competitiveness score. According to the institution type variable, it was determined that private school teachers had significantly higher scores than public school teachers compared to the competitiveness score. According to the linear regression that is done for determining the predicted level of teachers' competitiveness attitudes by educational beliefs, essentialism and perennialism determined positively their competitiveness attitudes; existential education belief predicts negatively and significantly.
\end{abstract}

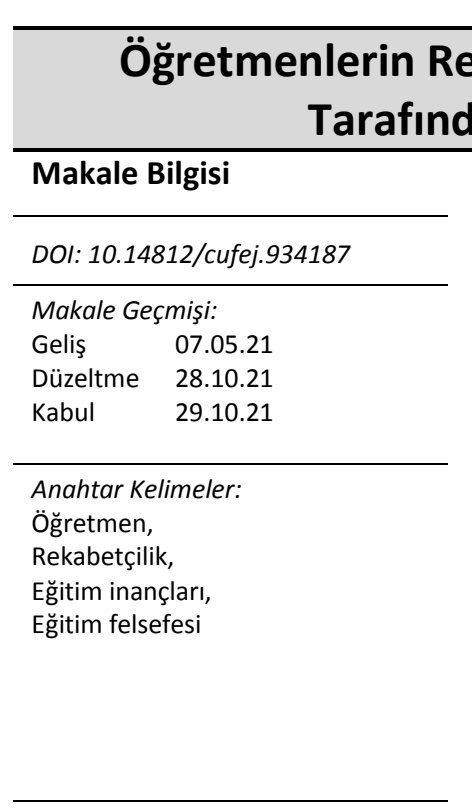
Yordanma Düzeyinin Belirlenmesi

\section{Öz}

Bu çalışmada öğretmenlerin eğitim felsefesi inançlarının rekabetçi tutumları yordama düzeyinin belirlenmesi amaçlanmıştır. Bu amaç çerçevesinde öğretmenlere dönük olarak iki farklı örneklem üzerinde açımlayıcı faktör analizi, güvenirlik analizi ve doğrulayıcı faktör analizleri yapılarak Öğretmenlerde Rekabetçilik Ölçeği geliştirilmiştir. Analizlerde ölçeğin yarışarak kazanma, onaylanma, üstünlük ve dışlama adı verilen 4 alt boyuttan ve 16 maddeden oluştuğu görülmüştür. İkinci ölçek olarak 40 madde ve 5 boyuttan oluşan Eğitim İnançları Ölçeği kullanılmıştır. İkinci örneklemde bağımsız gruplar $\mathrm{t}$ testi, korelasyon analizi ve çoklu regresyon analizi yapılmıştır. Yapılan analizlerde erkek öğretmenlerin kadın öğretmenlere göre yarışarak kazanma ve dışlama alt boyutları ile rekabetçilik toplam puanına göre anlamlı düzeyde yüksek puana sahip olduğu görülmüştür. Kurum tipi değişkenine göre özel okul öğretmenlerinin resmi okul öğretmenlerine göre onaylanma ve üstünlük alt boyutları ile rekabetçilik toplam puanına göre anlamlı düzeyde yüksek puana sahip oldukları belirlenmiştir. Öğretmenlerin rekabetçilik tutumlarının eğitim felsefesi inançları tarafından yordanma düzeyinin belirlenmesi için yapılan Doğrusal regresyon analizine göre esasicilik ve daimicilik felsefi inancı rekabetçilik tutumlarını pozitif yönde; varoluşçu eğitim inancı da negatif yönde ve anlamlı düzeyde yordamaktadır. 


\section{Introduction}

\section{Philosophy of education and educational theories}

Philosophy of education, which examines all issues related to education through philosophical investigations (Philips, 2019, p. 18), is closely related to the fields of study of philosophy such as epistemology and axiology, and sub-branches of philosophy such as philosophy of science and political philosophy. Such questions as "What are the aims of Education? Who, where, how and why should be trained? Should education be different from people's natural skills and abilities? What should be the role of the state in education?" are the most basic questions focused on in the philosophy of education (Noddings, 2017, p. 2; Gunzenhauser, 2003). Educational theories have tried to answer these and similar questions which arisen from both these and philosophical thoughts.

Idealism and Perennialism. According to idealism, which is a philosophical thought, the essence of the soul is reason and thinking. The truth, which is immutable, is achieved through reason. It is advocated that values will not change according to time and space and are objective (Cevizci, 2012, p. 25-6). There are different representatives of idealistic thought. But Plato's philosophy forms the foundations of the idealistic philosophy of education (Williams, 2019, p. 67). In society design of idealism, talent and knowledge are given importance. In this design, education is a tool for the functioning of politics and justice (Cevizci, 2012, p. 36). Individuals should be intertwined with the state and perform their duties in society by getting an education in accordance with their potential and essence within the social structure (Gökberk, 2012, p. 61; Noddings, 2017, p. 8). The function Plato put in education is to morally improve all the people of society, to reveal the natural potential of each person and to ensure that they develop to the extent of these potentials (Ünder, 1993). Gutek (2011, p. 26) expresses the duties imposed by the idealistic philosophy of education for the school as ensuring the students being aware of their innate abilities and transferring cultural heritage to students. Born as an educational theory based mainly on idealism, perennialism also gives priority to principles, unchangeable aspects of life, intellectual and spiritual development of man, not facts. Being a good person comes before vocational education (Cevizci, 2017, p. 343). Perennialists do not ignore vocational education. But they are opposed to giving more importance to vocational education than intellectual education (Gutek, 2011, p. 27). In perennialism, the teacher is the authority. The centre has teachers and course subjects. They also argue that students should not be given different piece of training, taking into account their individual differences and subjectivity (Moss \& Lee, 2010).

Realism and Essenitalism. Differing from idealism, realism emphasizes the reality of an external world independent from the mind and advocates that reality consists of matter and form. Human beings exist as body and soul. The most important feature that distinguishes humans from other living things is the mind (Cevizci, 2012, p. 45). Realism argues that reality has an objective order and that people have the ability to reach the knowledge of this reality. Therefore, education and teaching should be arranged according to this objective reality and the same education should be given to everyone (Gutek, 2011, p. 36-42). According to the Essentialism theory, which is significantly influenced by the principles of realism, students must gain the necessary knowledge and skills for social life. Students are obliged to get information from the teachers in the essential school setting where teachers are active. In essentialism, standardized tests are an ideal assessment tool to evaluate students' success and to see if teachers fulfil their academic responsibilities (Moss \& Lee, 2010). The theory that designs moral and intellectual education as a subject and teacher-centred manner is similar to perennialism in these aspects (Cevizci, 2017, p. 346).

Pragmatism and Progressivism. Pragmatism is a philosophical thought which is pluralist, specifies the subjectiveness and gives importance to the results in moral sentiment. It advocates that the human essence is not constant, emerged as a result of interaction with the social environment (Cevizci, 2012, p. 122). Progressivism which forms the philosophical basis of pragmatism is also a political thought that expresses the belief that man can change his own social and economic circumstances for the better in order to reduce the destructive effects of Liberalism (Oğuz, 2017). Educators influenced by this thought and pragmatism also developed a progressive education approach. The education models that are 
known as traditional and based on idealist and realist philosophy active in schools have been criticized by progressive educators especially John Dewey. According to the progressive educators traditional education wants to prepare the young people for the future which is accepted as if it will not be different from the past and imposes that they cannot be active while learning (Dewey, 2013, p. 21). For the progressive educators, education is determined externally and it turns the school into a different institution from other social institutions by an imposing mentality. According to Dewey schools should focus on the solution of the problems and improvement of scientific investigation skills of students'. On the other hand, in determining the educational goals, the interests of the child should be considered without being child-centred (Johnston, 2019, p. 104). For Dewey (2013, p. 32), the most important element of education is experience. However, experiences must be related and guide the student correctly. Values arise from people's reactions to events and facts in their environment. It's not constant and hierarchical. In the case of conflicting values, democracy is the most appropriate method to reconcile these conflicts (Gutek, 2011, p. 109).

Re-constructivism. Re-constructivism, although influenced by progressive understanding of education, it differs with its emphasis on socialism and some criticisms it brings to progressivism. It states that ideologies and educational theories are affected by social and cultural conditions and that culture can change continuously as a product of a dynamic process. Modern society is experiencing cultural crises and cannot overcome these crises. For this reason, the school should play a major role in rebuilding the society by questioning the past culture and living conditions and in resolving cultural crises (Gutek, 2011, p. 339). According to the re-constructive educators, unlike the progressivism theory, not individuals, but society consisting of individuals is important. School should be a place where social reforms will be applied and democracy and freedom will be settled in society (Altınkurt, Yılmaz \& Oğuz, 2012).

Existentialist education. Existentialist education focuses on the individual and opposes traditional, professional and positive science-based education approaches. By emphasizing subjective truths rather than objective truths, it calls the individual to take responsibility that is lost in communities. Existentialists, rejecting the claims that there is a defined meaning and rationality, advocate that the world is absurd (Cevizci, 2012, p. 147). Human is free as the maker of her/his existence. She/he makes own choices and takes responsibility. Thus, she/he adds meaning to her/his absurd life. Education is a process that liberates people and makes them aware of the responsibilities of their actions (Altınkurt et al., 2012). According to existentialist educators, education should not be confined to subject areas or a designated curriculum. School should be a place where the individual establishes a relationship with himself/herself and accesses the information he/she chooses and makes sense. Education should not have objective goals set for everyone (Gutek, 2011, p. 142). The teacher should not be at the centre but should provide students with an environment where they can get to know themselves, discuss freely, and choose suitable learning areas for themselves.

\section{Competitiveness and education}

Competition, which is a personal variation that has existed in the interaction of people with the same goal (Smither \& Houston, 1992), refers to struggling to achieve the same gain at the same time with other person or persons (Mead, 1937, p. 8). The aim of overtaking other people through better performance is the essence of competition. (Griffin-Pierson, 1990). Therefore, competitiveness requires competitors to achieve success in this sense. At the end of the competition process, there are always losers as well as winners (Simmons, King, Tucker \& Wehner, 1986). Kohn (1986, p. 4), who deals with competition in two different ways, states that the first aspect of the competition is a competition in which there are losers or winners. In this aspect, competition is a zero-sum event, resulting in winners reaching the prize. Having being rewards limited can lead to competition being stronger. On the other side of the competition, there is no tangible reward. The person makes an effort to show herself/himself as the best in an activity or group. Thus, she/he reaches the feeling that she/he is the best and experiences inner satisfaction. Griffen-Pierson (1990) emphasizes that besides the traditional competitiveness that is based on leaving others behind in achieving the goal, there is also goal-oriented 
competition, which means only reaching the goal and achieving excellence. In goal-oriented competition, the person can compete with herself/himself instead of others and struggle to reach the goal in the best way. However, while traditional meanings are very common in understanding competition, the meaning of goal-oriented competition is not common.

The individual begins to show competitive attitude from the moment he/she starts an activity or socialize with his/her peers (Tsiakara \& Digelidis, 2014). Riskind and Wilson (1982) state that the understanding that competitiveness is necessary to win in American society has become widespread and this understanding has an important role in developing a competitive attitude in the society. Hibbard \& Buhrmester (2010), on the other hand, emphasize the importance of social structure and state that competition is very important in individualist societies. Competitive attitude can be seen more intensely in societies where neoliberalism is effective which is based on individualism and individual benefits. The principles of neoliberalism in this way even shape the way of people live and think (Harvey, 2015, p. 1). Competition is not limited to business life; it becomes a norm wide enough to cover the private life of the person (Dardot \& Laval, 2012, p. 256). In neoliberalism, each individual must be selfresponsible to take care of himself/herself. Success and failure both belong to the individual (Foucault, 2015 , p. 125; Harvey, 2015, p. 73). In a neoliberal society, the productivity and success of the individual is more important than the security of laws as the source of rights (Curtis, 2015, p. 40). Thus, competitiveness becomes a mandatory rule for living well. Every individual can compete to avoid failure, to show herself, and to reach a limited amount of reward. This situation is frequently seen in the field of education like in all areas of life. Even the students can compete in different activities on their own or directly with the force of the teacher or the education system. According to Baudrillard (2010, p. 128) exams are the most distinguished form of advancement in society. While everyone wants to have status and higher income by passing examinations, they inevitably get into competition. Thus, competition becomes an unquestionable method for success, productivity and high status.

As seen, the widespread and strong competitive attitude is directly related to the social structure. Teachers and external factors play a role in the strength or weakness of competitive attitudes at school. On the other hand, studies with different findings have been done on the effect of competition on students' learning, success level, relationships with their environment and emotional states. According to Tauer and Harackiewicz (1999), competitiveness, especially in terms of academic success, can be perceived as a positive source of motivation in terms of challenging someone else and getting feedback about performance while reaching the goal. On the other hand, Humphreys, Johnson and Johnson (1982) concluded that collaboration is more effective on permanent learning and developing positive behaviours than competitiveness. Lam, Yim, Law and Cheung (2004) found that competitive attitude has positive aspects in the short-term but negative aspects in the long term in terms of variables such as academic achievement, self-assessment and learning motivation, and students who have competitive attitudes faced to mistakes are more negatively affected. Qin, Johnson and Johnson (1995) who state that there is a serious conflict in the literature about whether collaboration or competitiveness is better, examined the studies done between 1929-1995 using meta-analysis method. According to their findings, the collaborative approach gives more successful results than the competitive approach in solving problems and completing tasks. According to Thornton, Ryckman and Gold (2013) hypercompetitiveness and personal development competitiveness is different. In their study, personal development competitiveness was positively correlated to actual academic achievement, but hypercompetitiveness was not related. Ökmen, Şahin, Boyacı and Kılıç (2019), in their study about the effect of knowledge competitions among 5th grade students, determined that while many students felt excitement and joy before the competition, besides the loser also the winner had feelings of sadness, ambition and revenge after the competition because of competitiveness. The competition served the purpose of winning rather than learning. Kahveci and Sever (2018) determined that the competitiveness among high school students has increased. In addition, they determined that students can be cautious in sharing with each other due to the fact of the exam. 


\section{Importance and Purpose of the Research}

The attitudes and behaviours those teachers exhibit in their interactions with students significantly affect students' attitudes and behaviours and their motivation towards the lesson (Broeckelman Post, Tacconelli, Guzmán, Rios, Calero \& Latif, 2015; Sürücü \& Ünal, 2018). The fact that teachers' approaching students with a competitive attitude and compete students according to success and other criteria is in the quality that can have lasting effects in students' academic success and social relations. This effect, has a more negative side, as shown in the studies of Qin et al. (1995) and Lam et al. (2004). Ateş, Çetinkaya Özdemir and Taneri (2019) also state that competitive teachers conduct their teaching profession with a teacher-centred, authoritarian and traditional approach and this which has negative effects. Philosophy of education, which can be defined as a set of thoughts about educational purposes and values, guides relevant people in their choices and practices related to education (Gunzenhauser, 2003). Teachers' thoughts and educational beliefs can be effective in their behaviours within the school and their interactions with their students (Yılmaz, Altınkurt \& Çokluk, 2011; Kozikoğlu \& Erden, 2018; Doğanay, 2011). In this context, teachers' educational beliefs and their approaches to competitiveness can reflect in the classroom.

Determining the relationship between teachers' competitive attitudes and their educational beliefs is important in terms of revealing the factors behind teachers' competitive attitudes. In studies on similar subjects (Gill, 1986; Palmer \& Bejau, 1995; Cassidy (2008); Hibbard \& Buhrmester, 2010) it was found that attitudes and behaviors differ according to gender. There may be social and psychological reasons for this gender-related difference. It is seen that teachers working in private and public schools also have different attitudes and opinions in various studies (Kocabaş \& Karaköse, 2005; Karaköse \& Kocabaş, 2013; ilgar, 2014). In addition, since the working conditions and management approaches of both school types may differ, the institution type variable was also included in the research. For these reasons, it is thought that the findings on whether the competitive attitudes of teachers change according to gender and the type of institution (public-private) will contribute to academic studies on this subject. In the literature review, no study was found that revealed teachers' competitiveness attitudes or investigated the relationship between their philosophy of education beliefs and competitiveness attitudes. In this context, it can be said that the study has a unique aspect.

The aim of this study was to determine the level of predicting competitive attitudes of teachers' philosophy of education beliefs and the difference between teachers' competitive attitudes according to gender and type of institution. For this purpose, answers to the questions determined below were sought:

1- Do teachers' attitude levels towards competitiveness differ by gender?

2- Do teachers' attitude levels towards competitiveness differ according to the type of institution they work in?

3- Do teachers' educational beliefs predict their competitiveness attitudes?

\section{Method}

In this study, a descriptive causal relationship model, which is one of the quantitative research methods, was used. In this research model, the level of the relationship is determined by using the correlation coefficient between the variables (Neuman, 2007) and the value of the dependent variable is tried to be estimated according to the value of the independent variable (Büyüköztürk, Çokluk \& Köklü, 2012). In the study, the differentiation status of teachers' competitive attitudes according to gender and type of institution and the causal relationship between their philosophy of education beliefs and competitiveness attitudes were determined. 


\section{Participants}

In this study, data were collected from two different sample groups in Turkey. The data in the first group were collected for the Explanatory Factor Analysis done in order to determine the validity and reliability of the Teachers' Competitiveness Scale (TCS) in the second term of the 2019-2020 academic year. This sample group was selected on a voluntary basis through simple random sampling among 1677 teachers working in public and private schools in Balıkesir, Bandırma and Manyas districts. The sample group consisted of 211 women and 137 men, a total of 348 teachers. 253 of the teachers work in public schools and 95 of them work in private schools. On the basis of the branch there were 81 primary school, 26 pre-school, 38 Turkish, 41 foreign languages, 41 science, 26 social sciences, 33 mathematics, 31 religious culture and ethics teachers and 31 teachers in other branches.

Data on Education Beliefs Scale and Teachers Competitiveness Scale were collected from the second sample group. This sample group was selected by simple random sampling among 6402 teachers working in primary and secondary schools in Eskişehir city centre in the second term of the 2019-2020 academic year. The sample group consisted of 323 females, 122 males and 2 teachers who did not report their gender, a total of 447 teachers. 79 of the teachers work in private schools and 368 them work in public schools. The distribution of teachers by school level is 251 primary schools and 196 secondary schools. On the basis of the branch there were 196 primary school teachers, 35 pre-school, 26 Turkish, 25 foreign languages, 19 music, art and physical education, 17 science, 17 social sciences, 16 mathematics, 12 psychological counsellors and guidance, 6 religious culture and ethics teachers and 78 teachers who do not specify a branch.

\section{Data Collection Tools}

Teachers' Competitiveness Scale. The scale was developed by the researcher. Before the development of the scale, it was determined in the literature which is developed or adapted by GriffinPierson (1990) Houston, Farese and La Du (1992), Smither and Houston (1992) Helmreich and Spence (1978), Akbayırlı and Aydın (2000) that there are competitiveness scales, but no competitiveness scale prepared for teachers was encountered. For this reason, an item pool was formed with 30 items suitable for the relevant literature to measure teachers' competitiveness attitudes. The items were examined by 3 experts in the field of education and 2 items were removed because of not being suitable for the purpose of the scale. The 28-item scale is scored in the 5-point Likert type range of "1-Strongly Disagree and 5-Strongly Agree". In the development of the scale data obtained from two different sample groups were used. With the data obtained from the first sample group, exploratory factor analysis and reliability analysis were done using IBM SPSS Statistic 26 program. With the data obtained from the second sample group, confirmatory factor analysis was done using the $\mathrm{R}$ package program ( $\mathrm{R}$ Core Team, 2018) and the 'Lavaan' package (Rosseel, 2012).

It is stated that the sample size of at least 200 in a scale or per each scale item between 5 and 10 sample number is sufficient in order to do exploratory factor analysis (Worthington \& Whittaker, 2006). For this reason, it was seen that the number of 348 samples was sufficient for the 28 -item scale. In addition, the Kaiser-Mayer-Olkin (KMO) sample adequacy test should be greater than .60 (Tabachnick \& Fidell, 2007, p. 657). In this study, the KMO value was found to .84. Therefore, it was concluded that the sample size was sufficient for factor analysis. According to the Barlett's Test of Sphericity test, the chisquare value $(x 2=3030,807 ; p<.001)$ was found to be meaningful. Correlations between the items, correlation coefficients were determined to be above .30. After these findings, exploratory factor analysis was done to find out how many dimensions the sample perceived the questions and to reduce the number of variables. In Factor Analysis Maximum Likelihood method and Promax rotation technique were used. In the field of social sciences, it has been stated that these two methods give better results in contrast to science (Fabrigar et al., 1999; Worthington \& Whittaker, 2006). In the analysis starting with 28 items, a 4-factor structure was obtained by removing the items that were close to each other in different factors or the items remained single in one factor. The factor loads obtained range between 
KAHVECi - Çukurova Üniversitesi Eğitim Fakültesi Dergisi, 50(2), 2021, 1069-1099

.438 and .813 . The total variance rate explained by the 4 sub-dimension is .58 . The internal consistency coefficient calculated for the reliability of the scale was found to be .78 for the Cronbach Alpha $(\alpha)$ Confirmation dimension, .72 for the Winning by Competition dimension, .72 for the Exclusion dimension, .73 for the Superiority dimension and .82 for the whole scale. Descriptive values are presented in Table 1.

Table 1.

Descriptive Values Regarding Factors and Items

\begin{tabular}{|c|c|c|c|c|c|}
\hline Factors and items & $\begin{array}{l}\text { Explained } \\
\text { Variation (\%) }\end{array}$ & $\overline{\mathbf{x}}$ & SD & $\begin{array}{l}\text { Total } \\
\text { items } r\end{array}$ & $\begin{array}{l}\text { Factor } \\
\text { load }\end{array}$ \\
\hline \multicolumn{6}{|l|}{ Approval $(\alpha=0.78)$} \\
\hline M_8 & \multirow{4}{*}{27.188} & 3.3362 & 1.15345 & 0.344 & 0.813 \\
\hline M_9 & & 3.3879 & 1.12942 & 0.471 & 0.741 \\
\hline M_5 & & 3.7155 & 1.02819 & 0.363 & 0.624 \\
\hline M_21 & & 3.6379 & 1.08218 & 0.375 & 0.485 \\
\hline \multicolumn{6}{|c|}{ Winning by competition $(\alpha=0.72)$} \\
\hline M_4 & \multirow{4}{*}{16.101} & 2.3937 & 1.19686 & 0.521 & 0.722 \\
\hline M_18 & & 2.5575 & 1.16857 & 0.551 & 0.633 \\
\hline M_27 & & 2.3736 & 1.22820 & 0.439 & 0.596 \\
\hline M_25 & & 2.9511 & 1.23140 & 0.461 & 0.479 \\
\hline \multicolumn{6}{|l|}{ Exclusion $(\alpha=0.72)$} \\
\hline M_16 & \multirow{4}{*}{8.939} & 2.1408 & 1.07647 & 0.361 & 0.642 \\
\hline M_7 & & 2.4253 & 1.11714 & 0.387 & 0.638 \\
\hline M_12 & & 2.0316 & 1.06915 & 0.404 & 0.610 \\
\hline M_28 & & 1.6092 & 1.00553 & 0.256 & 0.593 \\
\hline \multicolumn{6}{|l|}{ Superiority $(\alpha=0.73)$} \\
\hline M_6 & \multirow{4}{*}{6.658} & 3.6695 & 1.07499 & 0.391 & 0.728 \\
\hline M_26 & & 3.6724 & 1.04185 & 0.370 & 0.673 \\
\hline M_17 & & 3.0431 & 1.17411 & 0.471 & 0.560 \\
\hline M_11 & & 3.0287 & 1.25635 & 0.555 & 0.438 \\
\hline Total $(\alpha=0,82)$ & 58.885 & & & & \\
\hline
\end{tabular}

In order to determine the item discrimination power of the dimensions formed with the exploratory factor analysis, the scores obtained from the scale were ranked in ascending order. The mean scores of the groups that make up the lower $27 \%$ and the upper $27 \%$ were compared with the independent group t-test and a significant difference was found between the group averages for all items at $p<.01$ level. Thus, it is seen that the items of the scale are distinctive between a high score and low score. In Table 2, independent groups t-test results are given to determine the discrimination power of items.

Table 2.

Test Results of The Item Discrimination Power of The Lower 27\% and Upper 27\% Groups

\begin{tabular}{|c|c|c|c|c|c|c|c|c|c|c|c|}
\hline \multicolumn{2}{|c|}{$\begin{array}{l}\text { Matched } \\
\text { Items }\end{array}$} & \multirow{2}{*}{$\frac{\overline{\mathbf{x}}}{1.00}$} & \multirow{2}{*}{$\begin{array}{l}\text { SD } \\
.00\end{array}$} & \multirow{3}{*}{$\begin{array}{c}\mathbf{t} \\
-39.46\end{array}$} & \multirow{3}{*}{$\begin{array}{r}\boldsymbol{p} \\
.00\end{array}$} & \multicolumn{2}{|c|}{ Matched Items } & \multirow{2}{*}{$\frac{\overline{\mathbf{x}}}{1.00}$} & \multirow{2}{*}{$\frac{\text { SD }}{.00}$} & \multirow{3}{*}{$\frac{\mathbf{t}}{-34.55}$} & \multirow{3}{*}{$\begin{array}{c}\boldsymbol{p} \\
.00\end{array}$} \\
\hline 4 & Low \%27 & & & & & 16 & LoW $_{\% 27}$ & & & & \\
\hline 4 & Up \%27 & 3.94 & .72 & & & 10 & Up \%27 & 3.54 & .71 & & \\
\hline \multirow{2}{*}{5} & Low $_{\% 27}$ & 2.47 & .71 & \multirow{2}{*}{-31.15} & \multirow{2}{*}{.00} & \multirow{2}{*}{17} & Low $_{\% 27}$ & 1.56 & .49 & \multirow{2}{*}{-39.26} & \multirow{2}{*}{.00} \\
\hline & $U p p_{\% 27}$ & 4.92 & .26 & & & & Up $\% 27$ & 4.40 & .49 & & \\
\hline \multirow{2}{*}{6} & Low $\% 27$ & 2.35 & .69 & \multirow{2}{*}{-30.02} & \multirow{2}{*}{.00} & \multirow{2}{*}{18} & LoW $_{\% 27}$ & 1.13 & .34 & \multirow{2}{*}{-42.72} & \multirow{2}{*}{.00} \\
\hline & Up \%27 & 4.93 & .25 & & & & Up \%27 & 4.03 & .55 & & \\
\hline \multirow{2}{*}{7} & LoW $_{\% 27}$ & 1.14 & .35 & \multirow{2}{*}{-31.46} & \multirow{2}{*}{.00} & \multirow{2}{*}{21} & LoW $_{\% 27}$ & 2.31 & .80 & \multirow{2}{*}{-27.58} & \multirow{2}{*}{.00} \\
\hline & Up $\% 27$ & 3.80 & .73 & & & & Up $\% 27$ & 4.84 & .36 & & \\
\hline
\end{tabular}


KAHVECI - Çukurova Üniversitesi Eğitim Fakültesi Dergisi, 50(2), 2021, 1069-1099

\begin{tabular}{|c|c|c|c|c|c|c|c|c|c|c|c|}
\hline \multirow{2}{*}{8} & Low \%27 & 1.90 & .65 & \multirow{2}{*}{-33.35} & \multirow{2}{*}{.00} & \multirow{2}{*}{25} & LoW\%27 & 1.40 & .49 & \multirow{2}{*}{-41.63} & \multirow{2}{*}{.00} \\
\hline & $U p$ \%27 & 4.68 & .46 & & & & Up \%27 & 4.39 & .49 & & \\
\hline \multirow{2}{*}{9} & Low \%27 & 1.95 & .62 & \multirow{2}{*}{-33.48} & \multirow{2}{*}{.00} & \multirow{2}{*}{26} & LoW $_{\% 27}$ & 2.34 & .54 & \multirow{2}{*}{-32.50} & \multirow{2}{*}{.00} \\
\hline & Up \%27 & 4.65 & .47 & & & & Up \%27 & 4.84 & .36 & & \\
\hline \multirow{2}{*}{11} & Low $\% 27$ & 1.52 & .50 & \multirow{2}{*}{-41.48} & \multirow{2}{*}{.00} & \multirow{2}{*}{27} & LoW $_{\% 27}$ & 1.00 & .00 & \multirow{2}{*}{-41.39} & \multirow{2}{*}{.00} \\
\hline & $U p p_{\% 27}$ & 4.55 & .49 & & & & Up $\% 27$ & 4.03 & .71 & & \\
\hline \multirow{2}{*}{12} & LoW \%27 & 1.00 & .00 & \multirow{2}{*}{32.71} & \multirow{2}{*}{.00} & \multirow{2}{*}{28} & LoW\%27 & 1.00 & .00 & \multirow{2}{*}{-17.61} & \multirow{2}{*}{.00} \\
\hline & $U p$ \%27 & 3.51 & .74 & & & & Up \%27 & 2.91 & 1.05 & & \\
\hline
\end{tabular}

Before the confirmatory factor analysis, an extreme value analysis was performed and 7 people were excluded from the analysis and the analysis was carried out with 440 people. It was also found that the data were distributed normally. According to the analysis results, the ratio of Chi-square Test $\left(\chi^{2}\right)$ to degrees of freedom is over 3 . The desired results were achieved as a result of error covariances between 6 and 7 and 13 and 14 . Accordingly, the ratio of Chi-square Test $\left(\chi^{2}=251\right)$ degrees of freedom $(\mathrm{df}=96)$ of the scale is 2.61; GFI value .93; CFI value .94; TLI value .93; NNFI value .93; IFI value .94; RMSEA value .06; SRMR value was determined to be .05 . Considering the recommendations in the literature, it can be argued that the scale shows good fit values (Hu \& Bentler, 1999; Kline, 2005; Schreiber, Nora, Stage, Barlow \& King, 2006). Factor loads and other values regarding the scale are shown in Table 3.

Table 3.

Results Regarding Factor Loads of Items of Teacher Competitiveness Scale

\begin{tabular}{lcccccc}
\hline Dimensions & Items & Factor Loads & sh & z-value & $\mathbf{p}$ & $\mathbf{R}^{\mathbf{2}}$ \\
\hline \multirow{3}{*}{ Winning by } & 1 & 0.66 & 0.05 & 12.90 & $<.001$ & 0.37 \\
competition & 11 & 0.78 & 0.06 & 13.67 & $<.001$ & 0.41 \\
& 13 & 0.77 & 0.06 & 13.91 & $<.001$ & 0.42 \\
& 15 & 0.63 & 0.05 & 11.74 & $<.001$ & 0.32 \\
\hline \multirow{4}{*}{ Approval } & 2 & 0.80 & 0.05 & 17.38 & $<.001$ & 0.59 \\
& 5 & 0.78 & 0.05 & 15.53 & $<.001$ & 0.50 \\
& 6 & 0.66 & 0.05 & 12.91 & $<.001$ & 0.38 \\
Superiority & 12 & 0.78 & 0.05 & 17.41 & $<.001$ & 0.59 \\
& 3 & 0.82 & 0.05 & 17.35 & $<.001$ & 0.56 \\
& 10 & 0.89 & 0.05 & 17.63 & $<.001$ & 0.57 \\
& 14 & 0.80 & 0.05 & 15.25 & $<.001$ & 0.46 \\
Exclusion & 4 & 0.81 & 0.05 & 16.60 & $<.001$ & 0.52 \\
& 8 & 0.52 & 0.06 & 9.23 & $<.001$ & 0.26 \\
& 9 & 0.71 & 0.05 & 14.77 & $<.001$ & 0.53 \\
\hline
\end{tabular}

When Table 3 is examined, it is seen that all items are in a significant relationship with the general scale structure and $z$ values are within specified ranges; it was seen that the factor loadings varied between .52 and .89 . The fact that these factor loads are above .50 proves the converging validity (Peterson, 2000). It was seen that all items of the scale have high $\mathrm{R}^{2}$ values (Cohen, 1988). The results of the confirmatory factor analysis of the scale are presented in Figure 1. 


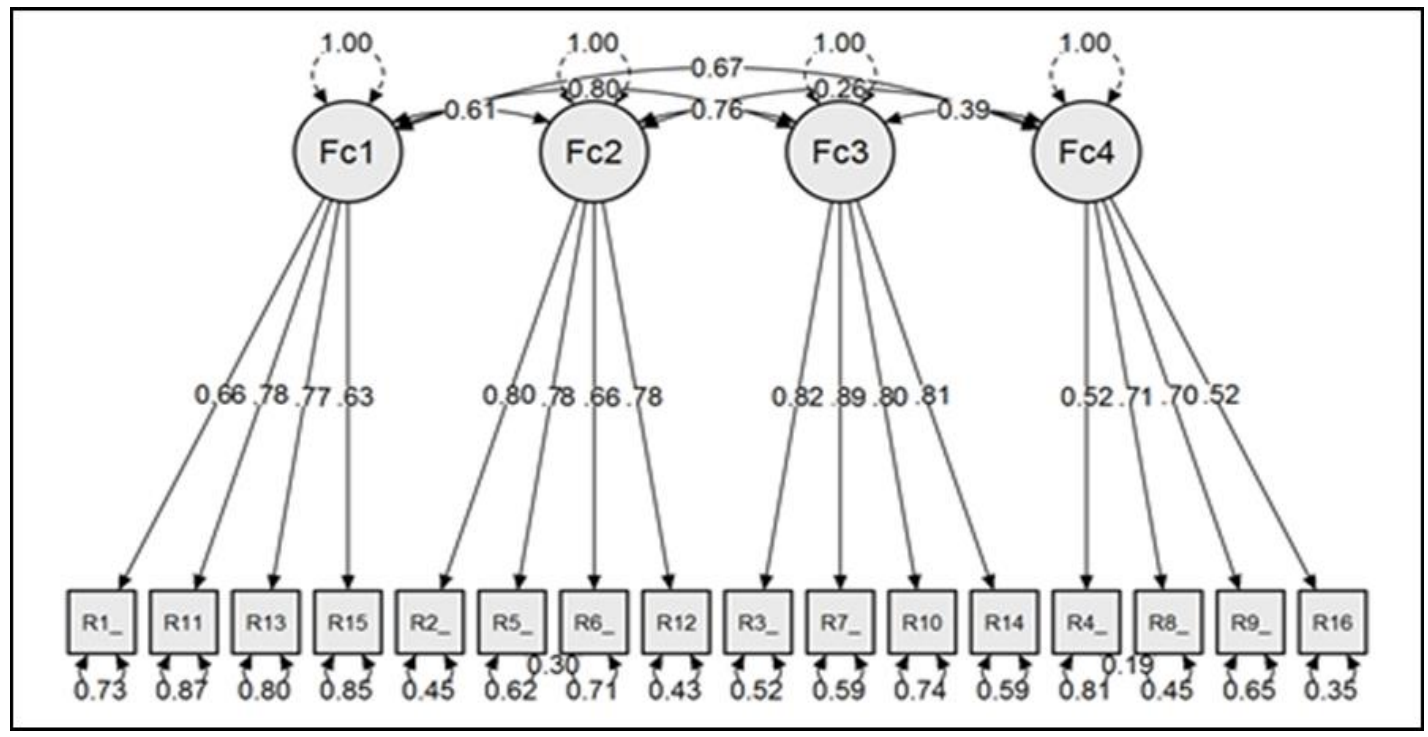

Figure 1. The Results of the Confirmatory Factor Analysis

Winning by Competition, which is one of the sub-dimensions of the scale, shows that the person considers the existence of competitors more important than the goal in achieving any work or goal. Winning by competing and leaving competitors behind is the most important source of motivation. The approval sub-dimension is related to the need for approval of the person or persons who are accepted as an external authority as a result of the work done instead of an award. It reflects the attitude of making a judgment about whether a person is successful in her/his job or not based on the views of external authorities. Even if there is not a reward, the superiority sub-dimension reflects the person's attitude of wanting to be the most successful and the best compared to other people. One's perception of perfection is associated with being superior to others. The exclusion dimension shows the individual's attitude of paying attention to a result-oriented success, giving more value to the successful ones and excluding those who fail. This dimension tries to determine the distinguishing attitude of the teacher between successful students and unsuccessful ones those whom he/she finds in favour of successful students.

Educational Beliefs Scale. Educational Beliefs Scale was developed by Yılmaz et al. (2011). The scale consists of 5 dimensions: progressivism, existential education, reconstructivism, perennialism and essentialism. The scale was prepared in a 5-point Likert type with 40 items, scored in the range of "1Absolutely Disagree and 5-Strongly Agree. For the sub-dimensions of the scale, the Cronbach Alpha internal consistency coefficient was calculated as .91 for progressivism, .89 for existential education, .81 for reconstructionism, .70 for perennialism and .70 for essentialism.

\section{Data Analysis}

The first data collected for the validity and reliability analysis of the Teachers' Competitiveness Scale were processed into the SPSS 26 package program. With these data Kaiser-Mayer-Olkin (KMO), Barlett's sphericity test, exploratory factor analysis and Cronbach Alpha $(\alpha)$ reliability analysis were performed. With the second data, confirmatory factor analysis of the Teachers' Competitiveness Scale was performed first. In order to determine the difference of competitiveness attitude according to gender and school type variable, first of all, normality tests were conducted. It was observed that all kurtosis and skewness values of the tests were between +2 and -2 . Since these values are sufficient to ensure normality (George \& Mallery, 2010), independent groups t-tests were performed. Then, correlation analysis and multiple regression analysis were performed for the relationship between teachers' competitiveness levels and educational beliefs. 


\section{Ethical Procedures}

Ethical principles and rules were followed in the planning, data collection, analysis and reporting process of the research. This research was ethically approved at the meeting numbered 2020/11 of Eskisehir Osmangazi University Scientific Research and Publication Ethics Committee on 20 May 2020.

\section{Findings}

Independent groups t-tests were done to determine the differences regarding competitiveness and sub-dimensions of competitiveness according to the gender variable of teachers. Quantitative findings related to this test are given in Table 4.

Table 4.

Independent Groups t-Test Results Regarding Competitiveness of Teachers and Sub Dimensions According to The Gender Variable

\begin{tabular}{|c|c|c|c|c|c|c|c|c|}
\hline Variables & Gender & $\mathbf{N}$ & $\overline{\mathbf{x}}$ & SD & df & $\mathbf{t}$ & $\mathbf{p}$ & d \\
\hline \multirow{2}{*}{$\begin{array}{l}\text { Winning by } \\
\text { competition }\end{array}$} & Female & 319 & 2.36 & .782 & \multirow{2}{*}{438} & \multirow{2}{*}{-2.58} & \multirow{2}{*}{.00} & \multirow{2}{*}{.29} \\
\hline & Male & 121 & 2.61 & .947 & & & & \\
\hline \multirow{2}{*}{ Approval } & Female & 319 & 3.74 & .837 & \multirow{2}{*}{438} & \multirow{2}{*}{1.01} & \multirow{2}{*}{.33} & \multirow{2}{*}{.11} \\
\hline & Male & 121 & 3.64 & .931 & & & & \\
\hline \multirow{2}{*}{ Superiority } & Female & 319 & 3.22 & .893 & \multirow{2}{*}{438} & \multirow{2}{*}{-1.57} & \multirow{2}{*}{.13} & \multirow{2}{*}{.16} \\
\hline & Male & 121 & 3.37 & .971 & & & & \\
\hline \multirow{2}{*}{ Exclusion } & Female & 319 & 1.86 & .693 & \multirow{2}{*}{438} & \multirow{2}{*}{-3.41} & \multirow{2}{*}{.00} & \multirow{2}{*}{.34} \\
\hline & Male & 121 & 2.12 & .812 & & & & \\
\hline \multirow{2}{*}{$\begin{array}{l}\text { Total score of } \\
\text { competitiveness }\end{array}$} & Female & 319 & 2.79 & .612 & \multirow{2}{*}{438} & \multirow{2}{*}{-1.92} & \multirow{2}{*}{.04} & \multirow{2}{*}{.22} \\
\hline & Male & 121 & 2.94 & .731 & & & & \\
\hline
\end{tabular}

According to the t-test results, it is seen that the total score of competitiveness significantly differentiates. Men's score is higher than women's $(t=-1.92, p=.04)$. While there is no difference in approval and superiority scores, which are sub-dimensions of competitiveness, there is a significant difference in favour of men in winning by competition and exclusion scores. The size of the difference in those who has a significant difference was calculated by the effect size (Cohen d). The effect size was medium level in the total score of competitiveness $(d=.23)$, medium level in the winning by competition sub-dimension $(d=.30)$ and medium level in the exclusion sub-dimension $(d=.35)$.

Independent groups t-tests were conducted to determine the differences in competitiveness and sub-dimensions of competitiveness according to the institution type variable. Quantitative data indicating the results of this test are given in Table 5.

Table 5.

Independent Groups t-Test Results Regarding Competitiveness of Teachers and Sub-Dimensions According to The Type of Institution Variable

\begin{tabular}{llccccccc}
\hline Variables & Group & $\mathbf{N}$ & $\overline{\mathbf{x}}$ & $\mathbf{S D}$ & $\mathbf{d f}$ & $\mathbf{t}$ & $\mathbf{p}$ & $\mathbf{d}$ \\
\hline Winning by & Public & 362 & 2.41 & .841 & \multirow{2}{*}{438} & -1.13 & .25 & .14 \\
competition & Private & 78 & 2.53 & .819 & & & & \\
\hline \multirow{2}{*}{ Approval } & Public & 362 & 3.64 & .877 & \multirow{2}{*}{438} & -3.62 & $.00 *$ & .48 \\
& Private & 78 & 4.03 & .723 & & & & \\
\hline \multirow{2}{*}{ Superiority } & Public & 362 & 3.20 & .943 & \multirow{2}{*}{438} & -3.60 & $.00 *$ & .40 \\
& Private & 78 & 3.54 & .720 & & & & \\
\hline
\end{tabular}


KAHVECi - Çukurova Üniversitesi Eğitim Fakültesi Dergisi, 50(2), 2021, 1069-1099

\begin{tabular}{llccccccc}
\hline \multirow{2}{*}{ Exclusion } & Public & 362 & 1.95 & .752 & \multirow{2}{*}{438} & 1.49 & .13 & .18 \\
& Private & 78 & 1.82 & .647 & & & & \\
\hline Total score of & Public & 362 & 2.80 & .665 & \multirow{2}{*}{438} & \multirow{2}{*}{-2.20} & $.02 *$ & .29 \\
competitiveness & Private & 78 & 2.98 & .554 & & & & \\
\hline
\end{tabular}

${ }^{*} p<0,05$

According to the institution type variable, there is a significant difference in favour of private school teachers in terms of competitiveness total score $(t=2.20, p=.02)$ and approval and superiority scores. The effect size was found to be medium in the total score of competitiveness $(d=.29)$, medium in the approval score $(\mathrm{d}=.48)$, and medium in the superiority score $(\mathrm{d}=.40)$.

Correlation analysis was done to determine the level of correlation between teachers' competitiveness scores and their educational beliefs scores and the direction of the correlation. Before the correlation analysis, the data of 5 people who had filled in the questionnaire in the educational beliefs section incompletely and incorrectly were removed and it's done with 435 people. Results of the analyses and descriptive statistics are shown in Table 6.

Table 6.

Correlation Coefficients Between Teachers' Competitiveness and Educational Beliefs and Descriptive Statistics Findings

\begin{tabular}{|c|c|c|c|c|c|c|}
\hline Variables & 1 & 2 & 3 & 4 & 5 & 6 \\
\hline 1. Competitiveness & - & & & & & \\
\hline 2. Progressivism & .011 & - & & & & \\
\hline 3. Existential Education & $-.157 * *$ & $.763 * * *$ & - & & & \\
\hline 4. Reconstructivism & .091 & $.553 * * *$ & $.495 * * *$ & - & & \\
\hline 5. Perennialism & $.112^{* *}$ & $.549 * * *$ & $.478 * * *$ & $.593 * * *$ & - & \\
\hline 6. Essentialism & $.304 * *$ & $-.165^{* *}$ & $-.254 * * *$ & .048 & $.200 * * *$ & - \\
\hline Average & 2.82 & 4.29 & 4.55 & 3.97 & 3.99 & 2.60 \\
\hline Standart Deviation & .64 & .42 & .44 & .57 & .50 & .71 \\
\hline Skewness & -0.12 & -0.57 & -.99 & -0.50 & -0.36 & 0.15 \\
\hline Kurtosis & 0.70 & 0.21 & 0.70 & -0.58 & -0.31 & -0.01 \\
\hline
\end{tabular}

$* \mathrm{p}<.05, * * \mathrm{p}<.01, * * * \mathrm{p}<.001$

According to the descriptive statistics obtained, all the variables showing the sub-dimensions of educational beliefs and competitiveness attitude are normally distributed. When the average scores are examined, teachers' competitiveness attitudes $(\bar{x}=2.82)$ are medium, progressivism ( $\bar{x}=4.29)$ in educational beliefs is very high, existential education $(\bar{x}=4.55)$ is very high, re-constructionism $(\bar{x}=3.97)$ is high, perennialism $(\bar{x}=3.99)$ is high and essentialism $(\bar{x}=2.60)$ has a low level score range. According to the correlation analysis, there was a negative correlation between teachers' competitiveness attitudes and existential education, and a positive correlation between perennialism and essentialism scores, while the correlation coefficient between them and other variables was found to be insignificant. After obtaining the correlation coefficients finding, multiple regression analysis was done to determine the prediction levels of competitiveness attitudes by educational beliefs. Analysis results are shown in Table 7. 
Table 7.

Multiple Regression Analysis Results Related to Determination of Predictive Power of Competitiveness by Educational Beliefs

\begin{tabular}{lcccccccccc}
\hline $\begin{array}{l}\text { Predictive } \\
\text { variables }\end{array}$ & $\mathbf{B}$ & $\begin{array}{c}\text { Std. } \\
\text { deviation }\end{array}$ & $\begin{array}{c}\text { Beta } \\
(\boldsymbol{\beta})\end{array}$ & $\mathbf{t}$ & $\mathbf{p}$ & $\boldsymbol{R}$ & $\boldsymbol{R}^{2}$ & $\boldsymbol{\Delta} \boldsymbol{R 2}$ & $\boldsymbol{F}$ & $\mathbf{p}$ \\
\hline $\begin{array}{l}\text { (Constant) } \\
\text { Existential }\end{array}$ & 2.656 & .361 & & 7.35 & .000 & .337 & .113 & .107 & 18.38 & .000 \\
Education & -.247 & .083 & -.168 & -2.97 & .003 & & & & & \\
Perennialism & .188 & .071 & .146 & 2.62 & .009 & & & & & \\
Essentialism & .212 & .046 & .232 & 4.58 & .000 & & & & & \\
\hline
\end{tabular}

$* * \mathrm{p}<.01$

Existential education, essentialism and perennialism, which are significant among the correlation coefficients between teachers' competitive attitudes, were included in the multiple regression analysis as independent variables, while progressivism and re-constructivism were not included in the analysis because of not having a significant correlation. According to the analysis, it was determined that the tolerance and VIF values are in the recommended range, and there is no autocorrelation and multiple linear connection problems. According to these findings regression results were found to be significant $\left(F_{(3,435)}=18.38, p=.000, R^{2}=.12\right)$. According to these results, teachers' existential educational beliefs are negatively predicting their competitiveness attitudes, while perennialism and essentialism beliefs positively predict. All variables explain $10.7 \%$ of teachers' competitiveness attitudes. According to the results obtained, teachers' competitiveness attitudes are predicted negatively by existentialist education beliefs, and essentialism and perennial beliefs are predicted positively.

\section{Discussion \& Conclusion}

It was seen that males had significantly higher scores than females in the winning by competition sub-dimension and moderately higher scores in effect size in the analysis done whether there is a difference between the scores of the teachers in terms of competitiveness and sub-dimensions according to gender variable. Hibbard and Buhrmester (2010) found that men have higher scores than women in competition for earnings. In addition, although the scores of the exclusion sub-dimension of both gender variables are low, the scores of males are higher than females. The effect size of this difference is also medium. On the other hand, total competitiveness scores were found to be significant in favour of men and high with medium effect size. These findings are in line with the findings of Gill (1986) and Cassidy (2008). The fact that men are more competitive than women, excluding failure and adopt competition focused on winning more shows that men adopt a progress focused on success, gain and material more. (Palmer \& Bejau, 1995). In addition, according to Hibbard and Buhrmester (2010), men giving importance to gain-oriented competitiveness by excluding failure may be related to the fact that they are more in disagreement with people in their social environment and have a weak sense of empathy. On the other hand, men's focusing on being stronger due to their traditional patriarchal roles and acting with the motivation to survive by winning may be another factor in the emergence of this finding.

In terms of the school type variable, the approval and superiority sub-dimensions and competitiveness total scores of private school teachers are significantly higher than those of public school teachers, and this difference has a medium effect size. This finding may be related to the working principles and conditions of the institutions studied. Titrek and Zafer (2009) determined that private school principals use organizational power resources at a higher level than official school principals. The higher use of legal, coercive and rewarding power in private schools may have resulted in private school teachers' greater need for approval by external authorities. Seçkin, Danışman and Babacan $(2014$, p. 77) state that teachers have serious competition with each other especially during contract periods and they try to get the approval of parents and administrators. Taşdan and Tiryaki (2010) found that private school teachers have higher scores in the dimension of job satisfaction development and promotion. 
Having private school teachers' high satisfaction with the opportunity of development and promotion may have caused them to adopt a more competitive attitude to seize this opportunity.

According to the results of the multiple regressions analysis done to determine teachers' predictive levels of their competitive attitudes, existentialism among educational beliefs negatively predicts competitiveness. As the belief in existential education gets stronger competitive attitude decreases according to this finding. Existential education puts the individual and the individual's liberty at the centre. As reported by Gül (2014), existentialism is not a thought that can be defined within a certain frame like different philosophical currents. Existentialism focuses on the meaning of human existence and possibilities of self-realization and keeps the social order and utility out of its field of interest. Tunca, Alkan-Şahin and Oğuz (2015) stated that the level of having an existential education belief as a professional value has a positive relationship with the variables of being open to cooperation, being against violence and respecting differences. This finding, when the characteristics of competitiveness are taken into consideration which is excluding cooperation and punishing failure, explains the negative relationship between the existentialist education belief and the attitude of competitiveness. Existentialism's strong emphasis on subjectivity brings a reaction to the conceptions of education and competitiveness that are claimed to ensure the continuation of inequality and the status quo. In the study done by Kozikoğlu and Erden (2018), it was found that there is a positive relationship between existentialist education philosophy and the level of adoption of critical pedagogy principles, although it's low. According to the critical pedagogy understanding, the current education order is oppressive. It is built on injustice and shaped by capitalist types of production. On the other hand, education should serve to liberate the individual, to gain a critical consciousness and to ensure justice (Cevizci, 2012, pp. 203-13). Pursuant to Gutek (2011, p. 142), the idea of existential education advocates a curriculum based on experiences and preferences, where the individual can evaluate life according to himself/herself. According to existentialists, the best learning is the one based on the information that student chooses his/her own and makes sense of. In this case, the current education system and curriculum are in a structure that does not give importance to the liberty and subjectivity of the individual, in the frame of the existentialist understanding. Teachers' being questioning and criticizing the existing system and keeping a distance from competitiveness with an existential perspective can be seen as their relation with their educational beliefs they have.

Essentialism and perennialism among teachers' educational beliefs positively predict their competitiveness attitudes respectively. Essentialism is a theory that feeds on realism and idealism philosophically and conflicts with contemporary educational theories. On the other hand, essentialism resembles liberal thinking by giving importance to values and knowledge that have the potential to increase social and economic values. Essentialism is being focused on academic achievement and knowledge learning and advocating a teacher-centred understanding (Gutek, 2011, pp. 301-303; Cevizci, 2012, pp. 48-54). And this situation explains its positive relationship with competitive attitude. In perennialist education it is aimed to improve people's mental abilities and teach unchangeable realities and universal truths with the assumption that human nature is unchangeable (Gutek, 2011, p. 306: Cevizci, 2012, p. 28). According to Plato, from whom Perennialism was affected significantly, people are not equal by nature and their education and their position in the society they will have should also be different. Every individual should be educated to the extent of his / her potential (Noddings, 2017, p. 8). Society is also naturally hierarchical structure just like an organism (Williams, 2019, p. 71). Also for the teachers who adopt Perennialism, the thought that a hierarchical and unequal society is natural and that everybody's deserved position in the society will provide justice may be effective. In this case, in determining who deserves what, competitiveness may have been given more positive meaning by accepting the ranking of people's success in their work and education life as an important criterion. Kozikoğlu and Erden (2018) determined that perennialism and essentialism have a low but negative relationship with critical pedagogical principles. Critical pedagogy's being against to the hierarchical classification of students and opposing liberalism's competitiveness, and its negative relationship with essentialism and perennialism in this aspect is similar to the findings of our study. Tunca et al. (2015) found in their study that essentialism has a negative relationship with the dimensions of being 
respectful to differences from professional values and being open to cooperation and that perennialism is also positive but it has a lower level than contemporary educational beliefs. Considering the nature of competitiveness that excludes cooperation and ignores respect for differences, it can be said that this finding supports this study. On the other hand, the fact that teachers who adopt essentialism and perennialism accept the information in the content of the curriculum as objective and accept only the test scores and the performance shown in the course as a criterion in determining whether the information is learned or not may have caused them to develop more positive attitudes towards competitiveness.

Beliefs and attitudes of teachers are one of the important factors in determining students' lives, learning levels and how individuals they will be in society (Yılmaz et al., 2011). For this reason, the effects of educational beliefs and theories on the educational process can be included in the teacher training programs, and it can be ensured that teachers know all aspects of the educational theories they will adopt.

Although competition provides a short-term motivation on the academic success of the student, in the long term it has negative effects on the realization of permanent learning (Lam et al., 2004). In addition, competitiveness has negative effects on students' emotional and social development (Ökmen et al., 2019; Kahveci \& Sever, 2018). On the other hand, considering the possibility that competitiveness may cause damage to interaction and cooperation between teachers, it can be suggested to inform teachers and education administrators about competitiveness in the light of the studies.

Since there is no study based on a causal relationship between educational beliefs and competitiveness and this study is limited to only one sample in a city centre similar studies can be repeated with qualitative or quantitative methods on different samples. In addition, researching the relationship of teachers with different variables related to their attitudes towards competitiveness is another issue that can be recommended for related researchers.

\section{Ethical Statement}

All rules included in the "Directive for Scientific Research and Publication Ethics in Higher Education Institutions" have been adhered to, and none of the "Actions Contrary to Scientific Research and Publication Ethics" included in the second section of the directive have been implemented. 


\title{
Türkçe Sürümü
}

\author{
Giriş
}

\section{Eğitim Felsefesi ve Eğitim Kuramları}

Eğitimle ilgili tüm meseleleri felsefî soruşturmalarla irdeleyen eğitim felsefesi (Philips, 2019, s. 18) epistomoloji ve aksiyoloji gibi felsefenin çalışma alanları ile bilim felsefesi ve siyaset felsefesi gibi felsefenin alt dallarıyla yakından ilişkilidir. "Eğitimin amaçları nelerdir? Kimler, nerede, nasıl ve niçin eğitilmeli? Eğitim, insanların doğal beceri ve eğilimlerinden farklı mı olmalı? Devletin eğitimdeki rolü ne olmalı?" gibi sorular eğitim felsefesinde üzerinde durulan en temel sorulardandır (Noddings, 2017, s. 2; Gunzenhauser, 2003). Bu ve benzeri sorulara gerek felsefi akımlardan gerekse bu akımlardan doğan eğitim kuramları cevap vermeye çalışmıştır.

İdealizm ve Daimicilik. Felsefi bir akım olan idealizme göre ruhun özü akıl ve düşünmedir. Değişmez olan hakikate akıl yoluyla ulaşılır. Değerlerin zamana ve mekâna göre değişmeyeceği ve nesnel olduğu savunulur (Cevizci, 2012, s. 25-6). İdealist akımın farklı temsilcileri vardır. Ancak Platon'un felsefesi idealist eğitim felsefesinin temellerini oluşturur (Williams, 2019, s. 67). İdealizmin toplum tasarısında demokrasi dışlanarak yeteneklere ve bilgiye önem verilir. Bu tasarımda siyaset ve adaletin işlevsellik kazanması için eğitim bir araçtır (Cevizci, 2012, s. 36). Bireyler devletle iç içe geçmeli ve toplumsal yapı içerisinde kendi potansiyeline ve özüne uygun bir eğitim alarak toplumda üzerine düşen görevleri yerine getirmelidir (Gökberk, 2012, s. 61; Noddings, 2017, s. 8). Platon'un eğitime yüklediği işlev, toplumun tüm bireylerini ahlâkî olarak iyileştirmek, her bireyin doğal potansiyelini ortaya çıkarmak ve bu potansiyelleri ölçüsünde gelişmesini sağlamaktır (Ünder, 1993). Gutek (2011, s. 26) idealist eğitim felsefesinin okula yüklediği görevleri öğrencilerin doğuştan getirdiği yetilerinin farkına varmasını sağlamak ve kültürel mirası öğrencilere aktarmak olarak ifade etmektedir. Ağırlıklı olarak İdealizme dayalı bir eğitim kuramı olarak doğan daimicilik de olgulara değil ilkelere, yaşamın değişmez yönlerine, insanın entelektüel ve manevi gelişimine öncelik verir. İyi insan olmak mesleki eğitimden daha önce gelir (Cevizci, 2017, s. 343). Daimiciler mesleki eğitimi yok saymazlar. Ancak mesleki eğitime entelektüel eğitimden daha fazla önem verilmesine karşı çıkarlar (Gutek, 2011, s. 27). Daimicilikte öğretmen otoritedir. Merkezde öğretmen ve ders konuları bulunur. Ayrıca daimiciler öğrencilerin bireysel farklılıklarını ve öznelliklerini dikkate alarak farklı eğitimler verilmemesi gerektiğini savunurlar (Moss ve Lee, 2010).

Realizm ve Esasicilik. İdealizmden farklı olarak zihinden bağımsız bir dış dünyanın gerçekliğine vurgu yapan realizm, gerçekliğin madde ile formdan meydana geldiğini savunmaktadır. İnsan da beden ve ruh olarak var olmaktadır. İnsanı diğer canlılardan ayıran en önemli özelliği aklıdır (Cevizci, 201, s. 45). Realizm gerçekliğin nesnel bir düzene sahip olduğunu ve insanların bu gerçekliğin bilgisine ulaşma yetisinin bulunduğunu savunmaktadır. Dolayısıyla eğitim ve öğretim bu nesnel gerçekliğe göre düzenlenmeli ve herkes için aynı eğitim verilmelidir (Gutek, 2011, s. 36-42). Realizmin ilkelerinden önemli ölçüde etkilenen esasicilik kuramına göre öğrenciler toplumsal yaşam için gerekli bilgi ve beceriler kazanmalıdır. Öğretmenlerin aktif olduğu esasici okul düzeninde öğrenciler öğretmenlerden bilgileri almakla yükümlüdürler. Esasicilikte standart testler hem öğrencilerin başarısını değerlendirmek hem de öğretmenlerin akademik sorumluğunu yerine getirip getirmediğini görmek için ideal bir değerlendirme aracıdır (Moss ve Lee; 2010). Ahlâki ve entelektüel eğitimi konu ve öğretmen merkezli biçimde tasarlayan kuram bu yönleriyle daimicilikle benzeşmektedir (Cevizci, 2017, s. 346).

Pragmatizm ve ilerlemecilik. Pragmatizm çoğulcu, öznelliği öne çıkaran ve ahlâk anlayışında sonuçlara önem veren felsefî bir akımdır. İnsanın özünün sabit olmadığını, sosyal çevresiyle etkileşimi sonucu ortaya çıktığını savunmaktadır (Cevizci, 2012, s. 122). Pragmatizmin felsefi temelini oluşturduğu ilerlemecilik de liberalizmin yıkıcı etkilerini azaltmak için insanın kendi sosyal ve ekonomik koşullarını iyi 
yönde değiştirebileceğine olan inancı dile getiren siyasal bir akımdır (Oğuz, 2017). Bu akımdan ve pragmatizmden etkilenen eğitimciler de ilerlemeci eğitim anlayışını geliş̧irmişlerdir. Geleneksel eğitim modeli olarak bilinen ve okullarda etkin olan idealist ve realist felsefeye dayalı eğitim modelleri başta John Dewey olmak üzere ilerlemeci eğitimcilerce eleştirilmiştir. Illerlemeci eğitimcilere göre geleneksel eğitim gençleri geçmişten farkı olmayacakmış gibi kabul edilen geleceğe hazırlamak istemekte ve onlara öğrenirken aktif olamayacakları bir yük yüklemektedir (Dewey, 2013, s. 21). ilerlemeci eğitimcilere göre eğitim dışarıdan belirlenmekte ve dayatmacı bir anlayışla okulu diğer sosyal kurumlardan farklı bir kurum hâline getirmektedir. Dewey'e göre okul, problemlerin çözümüne ve öğrencinin bilimsel soruşturma becerisinin geliştirilmesine yoğunlaşmalıdır. Diğer yandan eğitim amaçlarının belirlenmesinde çocuk merkezli olmadan çocuğun ilgileri dikkate alınmalıdır (Johnston, 2019, s. 104). Dewey (2013, s. 32) için eğitimin en önemli unsuru deneyimdir. Ancak deneyimler birbiriyle ilişki olmalı ve öğrenciyi doğru bir şekilde yönlendirmelidir. Değerler insanların çevrelerindeki olaylara ve olgulara gösterdiği tepkilerden kaynaklanır. Sabit ve hiyerarşik değildir. Değerlerin çatışması durumunda bu çatışmaları uzlaştırmak için demokrasi en uygun yöntemdir (Gutek, 2011, s. 109).

Yeniden Kurmacılık. Yeniden kurmacılık ilerlemeci eğitim anlayışından etkilenmekle birlikte toplumculuk vurgusuyla ve ilerlemeciliğe getirdiği kimi eleştirileriyle farklılaşır. İdeolojilerin ve eğitim kuramlarının toplumsal ve kültürel koşullardan etkilendiğini, kültürün de dinamik bir sürecin ürünü olarak sürekli değişebildiğini belirtmektedir. Modern toplum kültürel krizler yaşamakta ve bu krizleri aşamamaktadır. Bu nedenle okul, geçmiş kültür ve yaşam koşullarını sorgulayarak toplumun yeniden kurulması ve kültürel krizlerin çözülmesinde başat rol oynamalıdır (Gutek, 2011, s. 339). Yeniden kurmacı eğitimcilere göre ilerlemecilik kuramından farklı olarak birey değil, bireylerden oluşan toplum önemlidir. Okul sosyal reformların uygulanacağı, demokrasinin ve özgürlüğün topluma yerleşeceği bir yer olmalıdır (Altınkurt, Yılmaz ve Oğuz, 2012).

Varoluşçu Eğitim. Varoluşçu felsefeden etkilenen varoluş̧̧u eğitim bireye odaklanarak geleneksel ile mesleki ve pozitif bilim eksenli eğitim anlayışlarına karşı çıkar. Nesnel hakikatler yerine öznel hakikatlere vurgu yaparak topluluklar içinde kaybolan bireyi sorumluluk almaya çağııır. Belirlenmiş bir anlam ve akıllsallık olduğu iddialarını reddeden varoluşçular, dünyanın absürt olduğunu savunur (Cevizci, 2012, s. 147). İnsan kendi var oluşunun faili olarak özgürdür. Seçimlerini kendisi yapar ve bunun sorumluluğunu üstlenir. Böylece absürt olan yaşamına anlam katar. Eğitim de insanı özgürleştiren, eylemlerinin sorumluluklarının bilincine vardıran bir süreçtir (Altınkurt vd., 2012). Varoluşçu eğitimcilere göre eğitim konu alanlarına veya belirlenmiş bir öğretim programına sıkıştııımamalıdır. Okul, bireyin kendisiyle ilişki kurduğu, kendi seçtiği ve anlamlandırdığı bilgilere ulaştığı bir yer olmalıdır. Eğitimin herkes için belirlenmiş, nesnel amaçları olmamalıdır (Gutek, 2011, s. 142). Öğretmen merkezde olmamalı, öğrencilere kendilerini tanıyabilecekleri, özgürce tartışabilecekleri, kendilerine uygun öğrenme alanlarını seçebilecekleri bir ortamı sağlamalıdır.

\section{Rekabetçilik ve eğitim}

Aynı amacı hedefleyen insanların etkileşiminde var olagelmiş kişisel bir değişken (Smither ve Houston, 1992) olan rekabet, başka kişi ya da kişilerle aynı zamanda, aynı kazancı elde etmek için çabalamayı ifade etmektedir (Mead, 1937, s. 8). Rekabetin özünü daha iyi performans sergileyerek diğer kişileri geçme amacı oluşturmaktadır (Griffin-Pierson, 1990). Dolayısıyla bu anlamıyla rekabetçilik, başarıya ulaşma konusunda rakiplere gerek duyar. Rekabet sürecinin sonunda kazananın yanında mutlaka kaybedenler vardır (Simmons, King, Tucker ve Wehner, 1986). Rekabeti iki farklı yönde ele alan Kohn $(1986$, s. 4) rekabetin ilk yönünün mutlaka kaybedenlerin ve kazananların olduğu bir yarışma olduğunu belirtmektedir. Bu yönüyle rekabet sıfır toplamlı bir etkinlik olup kazananların ödüle ulaşmasıyla sonuçlanır. Ödülün sınırlı olması rekabetçiliğin daha güçlü biçimde ortaya çıkmasına neden olabilmektedir. Rekabetin diğer yönünde ise somut bir ödül yoktur. Kişi bir etkinlik veya grupta kendini en iyi olarak gösterme çabası gösterir. Böylece kendinin en iyi olduğu hissine ulaşarak içsel bir tatmin yaşamaktadır. Griffin-Pierson (1990) amaca ulaşma konusunda diğerlerini geride bırakmayı esas alan geleneksel rekabetçiliğin yanında sadece amaca ulaşmayı ve mükemmelliğe ulaşmayı ifade eden amaç 
odaklı rekabetin de olduğunu vurgulamaktadır. Amaç odaklı rekabette kişi başkaları yerine kendisiyle de yarışabilir ve hedefe en iyi şekilde ulaşmak için çabalayabilir. Ancak rekabetin anlaşılmasında geleneksel anlamlar çok yaygınken amaç odakı rekabetin içerdiği anlam yaygın değildir.

Birey akranlarıyla birlikte sosyalleşmeye veya bir etkinliğe başladığı anlardan itibaren rekabetçi tutum sergilemeye başlamaktadır (Tsiakara ve Digelidis, 2014). Riskind ve Wilson (1982) Amerikan toplumunda kazanmak için rekabetçiliğin gerekli olduğu anlayışının yaygınlaştığını ve bu anlayışın toplumun rekabetçi tutum geliştirmesinde önemli bir role sahip olduğunu belirtmektedir. Hibbard ve Buhrmester (2010) ise toplumsal yapının önemini vurgulayarak bireyci toplumlarda rekabetin çok önemsendiğini ifade etmektedir. Rekabetçi tutum bireyciliği ve bireysel çıkarları esas alan neoliberalizmin etkili olduğu toplumlarda daha yoğun görülebilmektedir. Neoliberalizmin bu yöndeki ilkeleri insanların yaşayış ve düşünüş biçimlerini dahi şekillendirmektedir (Harvey, 2015, s. 1). Rekabet bu bağlamda sadece iş hayatıyla sınırlı kalmamakta, kişinin özel hayatını kapsayacak genişlikte bir norm haline gelmektedir (Dardot ve Laval, 2012, s. 256). Neoliberalizmde her bireyin kendi başının çaresine bakmak için kendinden sorumlu olmalıdır. Başarı da başarısızlık da bireyin kendisine aittir (Foucault, 201, s. 125; Harvey, 2015, s. 73). Neoliberal bir toplumda hakların kaynağı olarak yasaların güvencesinden ziyade bireyin üretkenliği ve başarıları önemsenmektedir (Curtis, 2015, s. 40). Böylece rekabetçilik iyi yaşamak için zorunlu bir kural durumuna gelmektedir. Her birey başarısızlıktan kaçmak, kendini göstermek ve sınırlı miktardaki ödüle ulaşmak için rekabete girişebilmektedir. Bu durum yaşamın her alanında olduğu gibi eğitim alanında da sıkııla görülmektedir. Hatta öğrenciler farklı etkinliklerde kendi kendilerine ya da doğrudan öğretmen veya eğitim sisteminin zorlamasıyla rekabete girebilmektedir. Baudrillard'a (2010, s. 128) göre sınavlar toplumda yükselmenin en seçkin biçimidir. Herkes sınavlardan geçerek statüye ve daha yüksek gelire sahip olmak isterken, kaçınılmaz olarak rekabete girmektedir. Böylece başarı, üretkenlik ve yüksek statü için rekabet tartışılmaz bir yöntem haline gelmektedir.

Rekabetçi tutumun yaygın ve güçlü olması toplumsal yapıyla doğrudan ilişkilidir. Okulda rekabetçi tutumun güçlü veya zayıf olmasında öğretmenler ve dışsal faktörlerin rolü bulunmaktadır. Öte yandan rekabetin öğrencilerin öğrenmesine, başarı düzeyine, çevresiyle olan ilişkilerine ve duygusal durumlarına yaptığı etki konusunda farklı bulguları olan çalışmalar yapılmıştır. Tauer ve Harackiewicz'a (1999) göre özellikle akademik başarı konusunda rekabetçilik, kişinin başkasına meydan okuma ve hedefe ulaşırken performansıyla ilgili geri bildirim alma açısından olumlu bir motivasyon kaynağı olarak algılanabilmektedir. Buna karşın Humphreys, Johnson ve Johnson (1982) işbirlikçiliğin rekabetçiliğe göre kalıcı öğrenmeye ve olumlu davranış geliştirmeye daha fazla etki ettiği sonucuna ulaşmıştır. Lam, Yim, Law ve Cheung (2004) ise rekabetçi tutumun akademik başarı, kendini değerlendirme, öğrenme motivasyonu gibi değişkenler açısından kısa vadede olumlu ancak uzun vadede olumsuz yönleri olduğunu, hata karşısında rekabetçi tutuma sahip öğrencilerin daha olumsuz yönde etkilendiğini bulmuştur. İşbirlikçiliğin mi, yoksa rekabetçiliğin mi daha iyi olduğuna dair alan yazında ciddi bir çatışma bulunduğunu belirten Qin, Johnson ve Johnson (1995) 1929-1995 yılları arasında yapılan çalışmaları meta analiz yöntemiyle incelemiştir. Elde ettikleri bulgulara göre işbirlikçi yaklaşım problem çözme ve görevleri tamamlama konusunda rekabetçi yaklaşıma göre daha başarılı sonuçlar vermektedir. Thornton, Ryckman and Gold'a (2013) göre aşırı rekabetçilik ile kişisel gelişim rekabetçiliği birbirinden farklıdır. Çalışmalarında akademik başarıyla kişisel gelişim rekabetçiliğinin olumlu ilişkiye sahip olduğunu ama aşırı rekabetçilikle akademik başarı arasında olumlu ilişki olmadığını bulmuşlardır. Ökmen, Şahin, Boyacı ve Kılıç (2019) 5. sınıflar düzeyindeki öğrenciler arasında bilgi yarışmalarının etkisi hakkında yaptıkları çalışmada yarışma öncesi birçok öğrencinin heyecan ve sevinç duyarken yarışma sonrasında kaybedenlerin yanında kazananların da rekabetçilik nedeniyle üzüntü, hırs ve intikam gibi duygulara sahip olduğunu belirlemiştir. Yarışma öğrenmekten çok kazanma amacına hizmet etmiştir. Kahveci ve Sever (2018) lise öğrencileri arasında rekabetçiliğin arttı̆̆ını, öğrencilerin sınav olgusu nedeniyle birbirleriyle paylaşımlarında temkinli olabildiklerini, bilgiye de sınavlarda kendilerine getirecek yarar kadar değer verdiklerini belirlemişlerdir. 


\section{Araştırmanın Önemi ve Amacı}

Öğretmenlerin öğrencilerle etkileşimlerinde sergiledikleri tutum ve davranışlar öğrencilerin tutum ve davranışları ile derse karşı motivasyonlarını önemli ölçüde etkilemektedir (Broeckelman Post, Tacconelli, Guzmán, Rios, Calero ve Latif, 2015; Sürücü ve Ünal, 2018). Öğretmenlerin rekabetçi bir tutumla öğrencilere yaklaşması, öğrencileri başarı ve diğer ölçütlere göre yarıştırması öğrencilerin gerek akademik başarı düzeyine gerekse sosyal ilişkilerinde kalıcı etkiler bırakabilecek niteliktedir. Bu etki ise Qin vd. (1995) ile Lam vd. (2004) tarafından yapılan çalışmalarda da gösterildiği gibi daha çok olumsuz bir yöne sahiptir. Ateş, Çetinkaya Özdemir ve Taneri (2019) de rekabetçi öğretmenlerin daha çok öğretmen merkezli, otoriter ve geleneksel bir yaklaşımla öğretmenlik mesleği yürüttüğünü ve bu yaklaşımın olumsuz etkilere sahip olduğunu ifade etmektedir. Eğitimle ilgili amaçlar ve değerlere ilişkin düşünceler seti olarak tarif edilebilecek olan eğitim felsefesi, eğitimle ilgili seçimler ve pratiklerde ilgili kişilere rehberlik etmektedir (Gunzenhauser, 2003). Öğretmenlerin benimsedikleri düşünceler ve eğitim felsefesi inançları okul içindeki davranışlarında ve öğrencileriyle etkileşimlerinde etkili olabilmektedir (Yılmaz, Altınkurt ve Çokluk, 2011; Kozikoğlu ve Erden, 2018; Doğanay, 2011). Bu bağlamda öğretmenlerin benimsedikleri eğitim felsefesi inançları ile rekabetçiliğe ilişkin olumlu ya da olumsuz yaklaşımları sınıfa yansıyabilmektedir.

Öğretmenlerin rekabetçi tutuma sahip olması ile benimsedikleri eğitim felsefesi inançları arasındaki ilişkinin belirlenmesi öğretmenlerin rekabetçi tutumlarının gerisindeki etkenleri ortaya çıkarmak açııından önem taşımaktadır. Benzer konularda yapılan çalışmalarda (Gill, 1986; Palmer ve Bejau, 1995; Cassidy (2008); Hibbard ve Buhrmester, 2010) tutum ve davranışların cinsiyete göre farklılaştığı bulgusuna ulaşılmışır. Özel okullar ile kamu okullarında görev yapan öğretmenlerin çeşitli araştırmalarda farklı tutum ve görüşlere sahip olduğu (Kocabaş ve Karaköse, 2005; Karaköse ve Kocabaş, 2013; ilgar, 2014) görülmektedir. Ayrıca her iki okul tipinin çalışma koşulları ve yönetim anlayışları farklılaşabileceği için kurum tipi değişkeni de araştırma kapsamına alınmıştır. Öğretmenlerin rekabetçi tutumlarının cinsiyete ve görev yapılan kurum tipine (kamu-özel) göre değiş̧ip değişmediğine yönelik bulguların bu konuda yapılacak akademik çalışmalara katkı sağlayacak nitelikte olduğu düşünülmektedir. Alan yazın taramasında öğretmenlerin rekabetçilik tutumlarını ortaya çıkaran veya eğitim felsefesi inançlarıyla rekabetçilik tutumları arasındaki ilişkiyi araştıran bir çalışmaya rastlanmamıştır. Bu bağlamda çalışmanın özgün bir yönünün bulunduğu da söylenebilir.

Öğretmenlerin eğitim felsefesi inançlarının rekabetçi tutumları yordama düzeyinin belirlenerek öğretmenlerin rekabetçi tutumlarının cinsiyet ve görev yapılan kurum tipi değişkenine farklıık düzeyini belirlemek bu çalışmanın amacını oluşturmaktadır. Bu amaç çerçevesinde aşağıda belirlenen sorulara yanıt aranmıştır.

1- Öğretmenlerin rekabetçiliğe ilişkin tutum düzeyleri cinsiyete göre farklılaşmakta mıdır?

2- Öğretmenlerin rekabetçiliğe ilişkin tutum düzeyleri görev yaptıkları kurum türüne göre farklılaşmakta midır?

3- Öğretmenlerin benimsedikleri eğitim felsefesi inançları rekabetçilik tutumlarını yordamakta mıdır?

\section{Yöntem}

Bu çalışmada nicel araştırma yöntemlerinden betimsel nitelikli nedensel ilişki modeli kullanılmıştır. Bu araştırma modelinde değişkenler arası korelasyon katsayısı kullanılarak ilişkinin seviyesi belirlenmekte (Neuman, 2007) ve bağımlı değişkenin değeri, bağımsız değişkenin sahip olduğu değere göre tahmin edilmeye çalışılmaktadır (Büyüköztürk, Çokluk ve Köklü, 2012). Çalışmada öğretmenlerin rekabetçi tutumlarının cinsiyet ve kurum türü değişkenine göre farklılaşma durumları ile eğitim felsefesi inançları ve rekabetçilik tutumları arasındaki nedensel ilişki durumu belirlenmiştir. 


\section{Evren ve Örneklem}

Bu çalışmada iki ayrı örneklem grubundan veri toplanmıştır. Illk gruptaki veriler 2019-2020 öğretim yılı 2. döneminde Öğretmenlerde Rekabetçilik Ölçeği'nin (ÖRÖ) geçerlik ve güvenirliğinin belirlenmesi amacıyla yapılan Açımlayııı Faktör Analizi için toplanmıştır. Bu örneklem grubu Balıkesir ili, Bandırma ve Manyas ilçelerindeki resmi ve özel okullarda görev yapan 1677 öğretmen arasından basit tesadüfi örnekleme yoluyla gönüllülük esasına göre seçilmiştir. Örneklem grubunu 211 kadın, 137 erkek toplam 348 öğretmen oluşturmaktadır. Öğretmenlerin $253^{\prime}$ ü resmi, $95^{\prime} i$ özel okulda görev yapmaktadır. Örneklem grubu okul seviyesi bakımından 23 anaokulu, 111 ilkokul, 99 ortaokul ve 115 lise öğretmeninden oluşmaktadır. Branş bazında ise 81 sınıf, 41 fen bilimleri grubu, 41 yabancı dil, 38 Türkçe ve edebiyat grubu, 33 matematik, 31 Din kültürü ve ahlak bilgisi/iHL meslek dersleri, 26 okul öncesi, 26 sosyal bilimler grubu ve 31 diğer branşlardaki öğretmenler bulunmaktadır. Ölçek formları tüm okullara ulaştırıımış ve gönüllü olarak katılım sağlayan öğretmenler formları doldurmuşlardır.

Eğitim İnançları Ölçeği (EiO) ve ÖRÖ ile ilgili veriler ikinci örneklem grubundan toplanmıştır. Bu örneklem grubu Eskişehir il merkezindeki ilkokul ve ortaokullarda 2019-2020 öğretim yılı 2. döneminde görev yapan 6402 öğretmen arasından basit tesadüfi örnekleme yoluyla seçilmiştir. Örneklem grubunu seçilen okullardaki öğretmenlerden ölçek formunu doldurmaya gönüllü 323 kadın, 122 erkek ve 2 cinsiyet belirtmeyen toplamda 447 öğretmen oluşturmuştur. Örneklem grubundaki öğretmenlerin $79^{\prime} u$ özel, 368'i resmi okullarda görev yapmaktadır. Öğretmenlerin okul seviyesine göre dağııımı ise 251 ilkokul ve 196 ortaokul olarak gerçekleşmiştir. Branş bazında 196 sınıf, 35 okul öncesi, 26 Türkçe, 25 yabancı dil, 19 müzik, resim ve beden eğitimi, 17 fen bilimleri, 17 sosyal bilimler, 16 matematik, 12 Psikolojik danışman ve rehberlik, 6 din kültürü ve ahlak bilgisi öğretmeni ve 78 branş belirtmeyen öğretmen bulunmaktadır.

\section{Veri Toplama Araçları}

Öğretmelerde Rekabetçilik Ölçeği. Ölçek araştırmacı tarafından geliştirilmiştir. Ölçeğin geliştirilmesi öncesinde alan yazında Griffin-Pierson (1990) Houston, Farese ve La Du (1992), Smither ve Houston (1992) Helmreich ve Spence (1978) Aydın ve Akbağ (1997), Akbayırlı ve Aydın'ın (2000) geliştirdiği veya uyarladığı rekabetçilik ölçeklerinin olduğu belirlenmiş ancak öğretmenlere dönük olarak hazırlanan herhangi bir rekabetçilik ölçeğine rastlanmamıştır. Bu nedenle öğretmenlerin rekabetçilik tutumlarını ölçmek için ilgili alan yazına uygun olabilecek nitelikte 30 madde ile madde havuzu oluşturulmuştur. Maddeler eğitim alanında 3 uzman tarafından incelenmiş ve 2 madde ölçeğin amacına uygun bulunmadığı için çıkarılmıştır. 28 maddelik ölçek 5 'li Likert tipinde "1-Kesinlikle Katılmıyorum ve 5Kesinlikle Katılıyorum" aralığında puanlanmaktadır. Ölçeğin geliştirilmesinde iki farklı örneklem grubundan elde edilen veriler kullanılmıştır. Illk örneklem grubundan elde edilen verilerle IBM SPSS Statistic 26 programı kullanılarak açımlayıcı faktör analizi ve güvenirlik analizleri yapılmıştır. İkinci örneklem grubundan elde edilen verilerle R paket programı (R Core Team, 2018) 'Lavaan' paketi (Rosseel, 2012) kullanılarak doğrulayıcı faktör analizi yapılmışır.

Açımlayıcı faktör analizi yapabilmek için bir ölçekte en az 200 veya ölçek maddesi başına 5 ile 10 arasında örneklem sayısının yeterli olduğu ifade edilmektedir (Worthington ve Whittaker, 2006). Bu nedenle 28 maddelik ölçek için 348 örneklem sayısının yeterli olduğu görülmüştür. Ek olarak KaiserMayer-Olkin (KMO) örneklem yeterlilik testinin .60'tan büyük olması gerekmektedir (Tabachnick ve Fidell, 2007, s. 657). Bu çalışmada .84 olarak bulunarak örneklem büyüklüğünün faktör analizi için yeterli olduğu sonucuna ulaşıımıştır. Barlett's Test of Sphericity testine göre ki-kare değerinin $\left(x^{2}=3030,807\right.$; $p<.001)$ manidar olduğu bulunmuştur. Maddeler arasındaki korelasyonlar korelasyon katsayılarının .30 üzeri olduğu belirlenmiştir. Bu bulgulardan sonra örneklemin soruları kaç farklı boyutta algıladığını bulmak ve değişken sayısını azaltmak için açımlayıcı faktör analizi yapılmıştır. Faktör analizinde Maksimum Olabilirlik yöntemi ve Promax döndürme tekniği kullanılmıştır. Sosyal bilimler alanında fen bilimlerinin aksine bu iki yöntemin daha iyi sonuçlar verdiği belirtilmiştir (Fabrigar ve diğerleri, 1999; Worthington ve Whittaker, 2006). 28 madde ile başlanan analizde farklı faktörlerde birbirine yakın 
KAHVECI - Çukurova Üniversitesi Eğitim Fakültesi Dergisi, 50(2), 2021, 1069-1099

değerler alan veya bir faktörde tek kalan maddeler çıkarılarak 4 faktörlü bir yapı elde edilmiştir. Elde edilen faktör yükleri .438 ile .813 arasında değişmektedir. 4 alt boyutun açıkladığı toplam varyans oranı $.58^{\prime}$ dir. Ölçeğin güvenirliği için hesaplanan iç tutarlılık katsayısı Cronbach Alpha $(\alpha)$ Onaylanma boyutu için .78, Yarışarak Kazanma boyutu için .72, Dışlama boyutu için .72, Üstünlük boyutu için .73 ve ölçeğin tamamı için .82 olarak bulunmuştur. Bu bulgulara ait betimsel değerler Tablo 1'de sunulmuştur.

Tablo 1.

Faktör ve Maddelere ilişkin Betimsel Değerler

\begin{tabular}{|c|c|c|c|c|c|}
\hline Faktörler ve maddeler & $\begin{array}{c}\text { Açıklanan } \\
\text { varyans (\%) }\end{array}$ & $\overline{\mathbf{x}}$ & Ss & $\begin{array}{l}\text { Madde } \\
\text { toplam r }\end{array}$ & $\begin{array}{c}\text { Faktör } \\
\text { yükü }\end{array}$ \\
\hline \multicolumn{6}{|l|}{ Onaylanma ( $\alpha=0.78$ ) } \\
\hline M_8 & \multirow{4}{*}{27.188} & 3.3362 & 1.15345 & 0.344 & 0.813 \\
\hline M_9 & & 3.3879 & 1.12942 & 0.471 & 0.741 \\
\hline M_5 & & 3.7155 & 1.02819 & 0.363 & 0.624 \\
\hline M_21 & & 3.6379 & 1.08218 & 0.375 & 0.485 \\
\hline \multicolumn{6}{|c|}{ Yarışarak Kazanma ( $\alpha=0.72)$} \\
\hline M_4 & \multirow{4}{*}{16.101} & 2.3937 & 1.19686 & 0.521 & 0.722 \\
\hline M_18 & & 2.5575 & 1.16857 & 0.551 & 0.633 \\
\hline M_27 & & 2.3736 & 1.22820 & 0.439 & 0.596 \\
\hline M_25 & & 2.9511 & 1.23140 & 0.461 & 0.479 \\
\hline \multicolumn{6}{|l|}{ Dışlama ( $\alpha=0.72$ ) } \\
\hline M_16 & \multirow{4}{*}{8.939} & 2.1408 & 1.07647 & 0.361 & 0.642 \\
\hline M_7 & & 2.4253 & 1.11714 & 0.387 & 0.638 \\
\hline M_12 & & 2.0316 & 1.06915 & 0.404 & 0.610 \\
\hline M_28 & & 1.6092 & 1.00553 & 0.256 & 0.593 \\
\hline \multicolumn{6}{|l|}{ Üstünlük ( $\alpha=0.73)$} \\
\hline M_6 & \multirow{4}{*}{6.658} & 3.6695 & 1.07499 & 0.391 & 0.728 \\
\hline M_26 & & 3.6724 & 1.04185 & 0.370 & 0.673 \\
\hline M_17 & & 3.0431 & 1.17411 & 0.471 & 0.560 \\
\hline M_11 & & 3.0287 & 1.25635 & 0.555 & 0.438 \\
\hline Toplam $(\alpha=0,82)$ & 58.885 & & & & \\
\hline
\end{tabular}

Açımlayıc faktör analizi ile oluşan boyutların madde ayırt edicilik güçlerinin belirlenmesi için ölçekten elde edilen puanlar küçükten büyüğe doğru sıralanmıştır. Alt \%27 ve üst \%27'yi oluşturan grupların puan ortalamaları bağımsız grup t-testi ile karşılaştırılmış ve grup ortalamaları arasında tüm maddeler için p<.01 düzeyinde anlamlı bir fark olduğu görülmüştür. Böylece ölçek maddelerinin yüksek puan ile düşük puan arasında ayırt edici olduğu görülmektedir. Tablo 2'de maddelerin ayırt edicilik güçlerinin belirlenmesi için yapılan bağımsız gruplar t-testi sonuçları verilmiştir.

Tablo 2.

Alt \%27 ve Üst \%27'lik Grupların Madde Ayırt Edicilik Güçlerine Ait t Testi Sonuçları

\begin{tabular}{|c|c|c|c|c|c|c|c|c|c|c|c|}
\hline \multicolumn{2}{|c|}{$\begin{array}{l}\text { Eşleştirilen } \\
\text { Maddeler }\end{array}$} & \multirow{2}{*}{$\frac{\overline{\mathbf{x}}}{1.00}$} & \multirow{2}{*}{$\begin{array}{l}\text { SS } \\
.00\end{array}$} & \multirow{3}{*}{$\frac{\mathbf{t}}{-39.46}$} & \multirow{3}{*}{$\frac{\boldsymbol{p}}{.00}$} & \multicolumn{2}{|c|}{$\begin{array}{l}\text { Eşleştirilen } \\
\text { Maddeler }\end{array}$} & \multirow{2}{*}{$\begin{array}{c}\overline{\mathbf{x}} \\
1.00\end{array}$} & \multirow{2}{*}{$\frac{\text { SS }}{.00}$} & \multirow{3}{*}{$\frac{\mathbf{t}}{-34.55}$} & \multirow{3}{*}{$\begin{array}{c}\boldsymbol{p} \\
.00\end{array}$} \\
\hline & Alt $\% 27$ & & & & & & Alt $\% 27$ & & & & \\
\hline 4 & Üst \%27 & 3.94 & .72 & & & 16 & Üst $\% 27$ & 3.54 & .71 & & \\
\hline \multirow[b]{2}{*}{5} & Alt $\% 27$ & 2.47 & .71 & \multirow[b]{2}{*}{-31.15} & \multirow[b]{2}{*}{.00} & \multirow[b]{2}{*}{17} & Alt $\% 27$ & 1.56 & .49 & \multirow[b]{2}{*}{-39.26} & \multirow[b]{2}{*}{.00} \\
\hline & Üst \%27 & 4.92 & .26 & & & & Üst \%27 & 4.40 & .49 & & \\
\hline 6 & Alt $\% 27$ & 2.35 & .69 & -30.02 & .00 & 18 & Alt $\% 27$ & 1.13 & .34 & -42.72 & .00 \\
\hline
\end{tabular}


KAHVECI - Çukurova Üniversitesi Eğitim Fakültesi Dergisi, 50(2), 2021, 1069-1099

\begin{tabular}{|c|c|c|c|c|c|c|c|c|c|c|c|}
\hline & Üst \%27 & 4.93 & .25 & & & & Üst \%27 & 4.03 & .55 & & \\
\hline \multirow{2}{*}{7} & Alt $\% 27$ & 1.14 & .35 & \multirow{2}{*}{-31.46} & \multirow{2}{*}{.00} & \multirow{2}{*}{21} & Alt $\% 27$ & 2.31 & .80 & \multirow{2}{*}{-27.58} & \multirow{2}{*}{.00} \\
\hline & Üst \%27 & 3.80 & .73 & & & & Üst \%27 & 4.84 & .36 & & \\
\hline \multirow{2}{*}{8} & Alt $\% 27$ & 1.90 & .65 & \multirow{2}{*}{-33.35} & \multirow{2}{*}{.00} & \multirow{2}{*}{25} & Alt $\% 27$ & 1.40 & .49 & \multirow{2}{*}{-41.63} & \multirow{2}{*}{.00} \\
\hline & Üst \%27 & 4.68 & .46 & & & & Üst \%27 & 4.39 & .49 & & \\
\hline \multirow{2}{*}{9} & Alt $\% 27$ & 1.95 & .62 & \multirow{2}{*}{-33.48} & \multirow{2}{*}{.00} & \multirow{2}{*}{26} & Alt $\% 27$ & 2.34 & .54 & \multirow{2}{*}{-32.50} & \multirow{2}{*}{.00} \\
\hline & Üst \%27 & 4.65 & .47 & & & & Üst \%27 & 4.84 & .36 & & \\
\hline \multirow{2}{*}{11} & Alt \%27 & 1.52 & .50 & \multirow{2}{*}{-41.48} & \multirow{2}{*}{.00} & \multirow{2}{*}{27} & Alt $\% 27$ & 1.00 & .00 & \multirow{2}{*}{-41.39} & \multirow{2}{*}{.00} \\
\hline & Üst \%27 & 4.55 & .49 & & & & Üst \%27 & 4.03 & .71 & & \\
\hline \multirow{2}{*}{12} & Alt $\% 27$ & 1.00 & .00 & \multirow[t]{2}{*}{32.71} & \multirow[t]{2}{*}{.00} & \multirow{2}{*}{28} & Alt \%27 & 1.00 & .00 & \multirow[t]{2}{*}{-17.61} & \multirow[t]{2}{*}{.00} \\
\hline & Üst \%27 & 3.51 & .74 & & & & Üst \%27 & 2.91 & 1.05 & & \\
\hline
\end{tabular}

Doğrulayıcı faktör analizi öncesinde uç değer analizi yapılmış ve 7 kişi analizden çıkarılıp 440 kişi ile analiz gerçekleştirilmiştir. Ayrıca verilerin normal dağıldığı tespit edilmiştir. Analiz sonuçlarına göre Kikare Testinin (x2) serbestlik derecelerine oranının 3'ün üstünde olduğu görülmüştür. 6 ile 7 ve 13 ile 14 arasında yapılan hata kovaryansları sonucu ile istenilen sonuçlara ulaşılmıştır. Buna göre ölçeğin Ki-kare Test $(\chi 2=251)$ serbestlik derecesi ( $d f=96)$ oranının 2.61; GFI değeri .93; CFI değeri .94; TLI değeri .93; NNFI değeri .93; IFI değeri .94; RMSEA değeri .06; SRMR değerinin ise .05 olduğu belirlenmiştir. Alan yazındaki öneriler göz önünde bulundurulduğunda ölçeğin iyi uyum değerleri gösterdiği savunulabilir (Hu ve Bentler, 1999; Kline, 2005; Schreiber, Nora, Stage, Barlow, ve King, 2006). Ölçeğe ilişkin faktör yükleri ve diğer değerler Tablo 3'te gösterilmiştir.

Tablo 3.

Öğretmen Rekabetçilik Ölçeği Maddeleri Faktör Yüklerine ilişkin Sonuçlar

\begin{tabular}{lcccccc}
\hline Boyutlar & Maddeler & Faktör yükü & sh & z-değeri & $\mathbf{p}$ & $\mathbf{R}^{\mathbf{2}}$ \\
\hline \multirow{3}{*}{ Yarışarak kazanma } & 1 & 0.66 & 0.05 & 12.90 & $<.001$ & 0.37 \\
& 11 & 0.78 & 0.06 & 13.67 & $<.001$ & 0.41 \\
& 13 & 0.77 & 0.06 & 13.91 & $<.001$ & 0.42 \\
Onaylanma & 15 & 0.63 & 0.05 & 11.74 & $<.001$ & 0.32 \\
\hline \multirow{3}{*}{ Üstünlük } & 2 & 0.80 & 0.05 & 17.38 & $<.001$ & 0.59 \\
& 5 & 0.78 & 0.05 & 15.53 & $<.001$ & 0.50 \\
& 6 & 0.66 & 0.05 & 12.91 & $<.001$ & 0.38 \\
& 12 & 0.78 & 0.05 & 17.41 & $<.001$ & 0.59 \\
\hline \multirow{3}{*}{ Dışlama } & 3 & 0.82 & 0.05 & 17.35 & $<.001$ & 0.56 \\
& 7 & 0.89 & 0.05 & 17.63 & $<.001$ & 0.57 \\
& 10 & 0.80 & 0.05 & 15.25 & $<.001$ & 0.46 \\
& 14 & 0.81 & 0.05 & 16.60 & $<.001$ & 0.52 \\
\hline
\end{tabular}

Tablo 3 incelendiğinde bütün maddelerin genel ölçek yapısı ile anlamlı ilişki içinde olduğu ve z değerlerinin belirlenen aralıklarda olduğu; faktör yüklerinin .52 ile .89 arasında değiştiği görülmüştür. Elde edilen bu faktör yüklerinin .50 üzeri olması yakınsama geçerliliğine kanıt teşkil etmektedir (Peterson, 2000). Ölçeğin bütün maddelerinin yüksek $R^{2}$ değerine sahip olduğu görülmüştür (Cohen, 1988). Ölçeğin doğrulayıcı faktör analizine ilişkin sonuçlar Şekil 1'de sunulmuştur. 


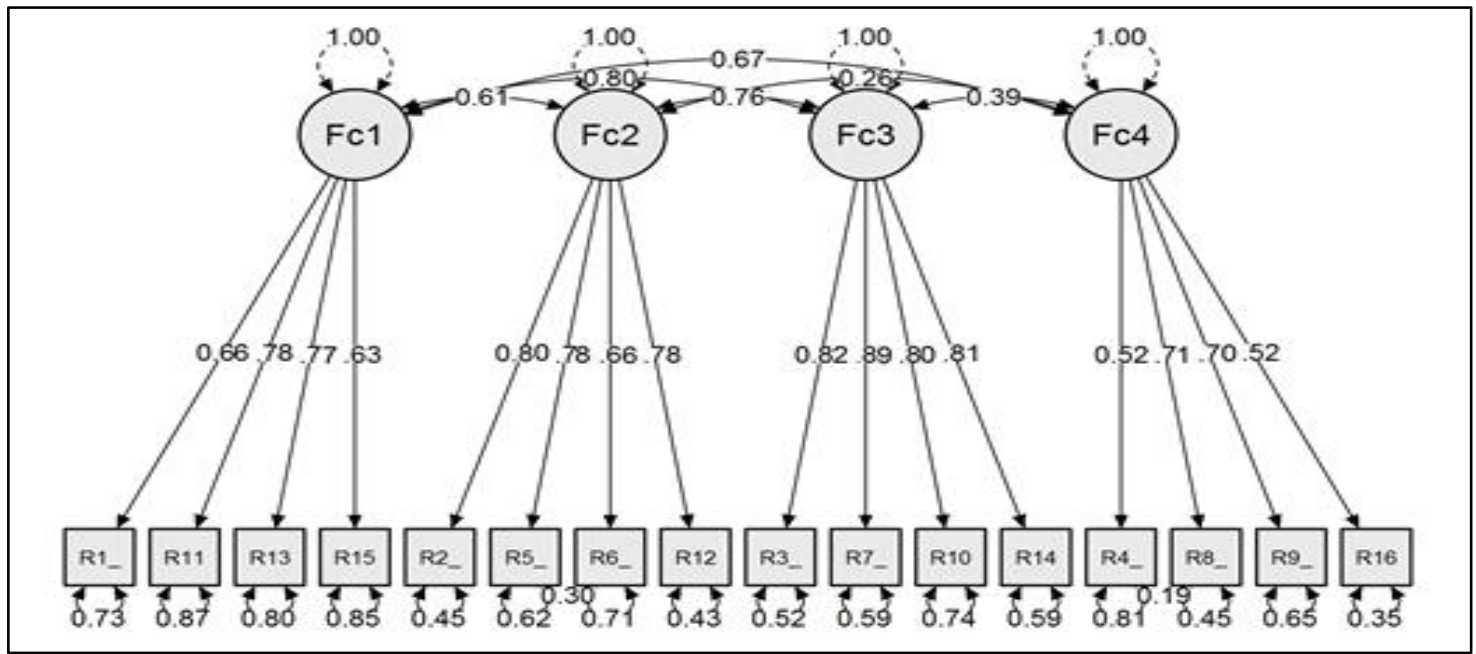

Şekil 1. Doğrulayıcı Faktör Analizine İlişkin Sonuçlar

Ölçeğin alt boyutlarından Yarışarak Kazanma kişinin herhangi bir işi yapma veya amaca ulaşmada rakiplerin varlığını amaçtan daha önemli gördüğünü göstermektedir. Yarışarak ve rakipleri geride bırakarak kazanmak en önemli motivasyon kaynağıdır. Onaylanma alt boyutu bir ödül yerine yapılan işin sonucunda dış otorite olarak kabul edilen kişi ya da kişilerin onayına duyulan ihtiyaçla ilişkilidir. Kişinin yaptığı işte başarılı olup olmadığına ilişkin yargısını dış otoritelerin görüşlerine göre oluşturma tutumunu yansıtmaktadır. Üstünlük alt boyutu bir ödül olmasa bile kişinin diğer kişilere göre en başarılı ve en iyi olmayı isteme tutumunu yansıtmaktadır. Kişinin mükemmellik algısı diğer kişilerden daha üstün olmasıyla ilişkilidir. Dışlama boyutu ise bireyin sonuç odaklı bir başarıyı önemseme, başarılı olanlara daha fazla değer verme ve başarısız olanları dışlama tutumunu göstermektedir. Bu boyut öğretmenin başarılı öğrencilerle başarısız bulduğu öğrenciler arasında başarılı olanlar lehine ayrım yapma tutumunu belirlemeye çalışmaktadır.

Eğitim İnançları Ölçeği. Eğitim İnançları Ölçeği (Eiö) Yılmaz vd. (2011) tarafından geliştirilmiştir. Ölçek, ilerlemecilik, varoluşçu eğitim, yeniden kurmacılık, daimicilik ve esasicilik olmak üzere 5 boyuttan oluşmaktadır. Ölçek 40 maddelik, "1-Kesinlikle Katılmıyorum ve 5-Kesinlikle Katılıyorum aralığında puanlanan $5^{\prime}$ li Likert tipinde hazırlanmıştır. Ölçeğin alt boyutları için Cronbach Alfa iç tutarlılık katsayısı ilerlemecilik için .91, varoluşçu eğitim için .89, yeniden kurmacılık için .81, daimicilik için .70 ve esasicilik için .70 olarak hesaplanmıştır.

\section{Verilerin Analizi}

ÖRÖ’nün geçerlik ve güvenirlik analizleri için toplanan ilk veriler SPSS 26 paket programına işlenmiştir. Bu verilerle Kaiser-Mayer-Olkin (KMO), Barlett's küresellik testi, açımlayıcı faktör analizi ve Cronbach Alpha $(\alpha)$ güvenirlik analizi yapılmıştır. ÖRÖ’nün doğrulayıcı faktör analizi ve çalışmanın amacı için toplanan ikinci verilerle önce Öğretmenlerde Rekabetçilik Ölçeği'ne ait doğrulayıcı faktör analizi yapılmıştır. Rekabetçilik tutumunun cinsiyet ve okul türü değişkenine göre farkını belirlemeden önce normallik testleri yapılmıştır. Testlerin tüm basıklık ve çarpıklık değerlerinin +2 ve -2 arasında olduğu görülmüştür. Bu değerler normalliğin sağlanması için yeterli olduğundan (George ve Mallery, 2010) bağımsız gruplar $\mathrm{t}$ testi bulguları incelenmiştir. Öğretmenlerin rekabetçilik düzeylerinin eğitim inançlarıyla ilişkisi için de korelasyon analizi ve çoklu regresyon analizi yapılmıştır. 


\section{Etik Prosedürler}

Araştırmanın planlama, veri toplama, analiz ve raporlama sürecinde etik ilke ve kurallara uyulmuştur. Bu araştırma Eskişehir Osmangazi Üniversitesi Bilimsel Araştırma ve Yayın Etiği Kurulu'nun 20 Mayıs 2020 tarihinde yaptığı 2020/11 sayılı toplantısında etik olarak uygun görülmüştür.

\section{Bulgular}

Öğretmenlerin cinsiyet değişkenine göre rekabetçilik ve rekabetçiliğin alt boyutlarına ilişkin farkları belirlemek için bağımsız gruplar t testi yapılmıştır. Bu teste ilişkin sayısal bulgular Tablo 4'te verilmiştir.

Tablo 4.

Cinsiyet Değişkenine Göre Öğretmenlerin Rekabetçilik ve Alt Boyutlarına Ilişkin Bağımsız Gruplar t testi Sonuçları

\begin{tabular}{|c|c|c|c|c|c|c|c|c|}
\hline Değişken & Cinsiyet & $\mathbf{N}$ & $\overline{\mathbf{x}}$ & Ss & Sd & $\mathbf{t}$ & p & d \\
\hline \multirow{2}{*}{ Yarışarak Kazanma } & Kadın & 319 & 2.36 & .782 & \multirow{2}{*}{438} & \multirow{2}{*}{-2.58} & \multirow{2}{*}{.00} & \multirow{2}{*}{.29} \\
\hline & Erkek & 121 & 2.61 & .947 & & & & \\
\hline \multirow{2}{*}{ Onaylanma } & Kadın & 319 & 3.74 & .837 & \multirow{2}{*}{438} & \multirow{2}{*}{1.01} & \multirow{2}{*}{.33} & \multirow{2}{*}{.11} \\
\hline & Erkek & 121 & 3.64 & .931 & & & & \\
\hline \multirow{2}{*}{ Üstünlük } & Kadın & 319 & 3.22 & .893 & \multirow{2}{*}{438} & \multirow{2}{*}{-1.57} & \multirow{2}{*}{.13} & \multirow{2}{*}{.16} \\
\hline & Erkek & 121 & 3.37 & .971 & & & & \\
\hline \multirow{2}{*}{ Dışlama } & Kadın & 319 & 1.86 & .693 & \multirow{2}{*}{438} & \multirow{2}{*}{-3.41} & \multirow{2}{*}{.00} & \multirow{2}{*}{.34} \\
\hline & Erkek & 121 & 2.12 & .812 & & & & \\
\hline \multirow{2}{*}{ Rekabetçilik Toplam } & Kadın & 319 & 2.79 & .612 & \multirow{2}{*}{438} & \multirow{2}{*}{-1.92} & \multirow{2}{*}{.04} & \multirow{2}{*}{.22} \\
\hline & Erkek & 121 & 2.94 & .731 & & & & \\
\hline
\end{tabular}

${ }^{*} p<0,05$

Bağımsız gruplar t testi sonuçlarına göre rekabetçilik toplam puanının erkeklerin lehine anlamlı yönde farklılaştığı $(t=1.92, p=.04)$ görülmektedir. Rekabetçiliğin alt boyutlarından onaylanma ve üstünlük puanlarında fark bulunmazken, yarışarak kazanma ve dışlama puanlarında erkeklerin lehine anlamlı fark görülmektedir. Anlamlı farka sahip olanlarda farkın büyüklüğü etki büyüklüğü (Cohen d) ile hesaplanmıştır. Etki büyüklüğü Rekabetçilik toplam puanında $(d=.23)$ orta düzeyde, yarışarak kazanma alt boyutunda $(\mathrm{d}=.30)$ orta ve dışlama alt boyutunda $(\mathrm{d}=.35)$ orta düzeyde bulunmuştur.

Öğretmenlerin görev yaptıkları okulların kurum türü değişkenine göre rekabetçilik ve rekabetçiliğin alt boyutlarına ilişkin farkları belirlemek için bağımsız gruplar t testi yapılmıştır. Bu testin sonuçlarını belirten sayısal veriler Tablo 5'te verilmiştir.

Tablo 5.

Kurum Türü Değişkenine Göre Öğretmenlerin Rekabetçilik ve Alt Boyutlarına İlişkin Bağımsız Gruplar $t$ Testi Sonuçları

\begin{tabular}{llccccccc}
\hline Değişken & Grup & $\mathbf{N}$ & $\overline{\mathbf{x}}$ & Ss & Sd & $\mathbf{t}$ & $\mathbf{p}$ & $\mathbf{d}$ \\
\hline Yarışarak & Resmi & 362 & 2.41 & .841 & \multirow{2}{*}{438} & -1.13 & .25 & .14 \\
Kazanma & Özel & 78 & 2.53 & .819 & & & & \\
\hline \multirow{2}{*}{ Onaylanma } & Resmi & 362 & 3.64 & .877 & \multirow{2}{*}{438} & -3.62 & .00 & .48 \\
& Özel & 78 & 4.03 & .723 & & & \multirow{2}{*}{.43} \\
Üstünlük & Resmi & 362 & 3.20 & .943 & \multirow{2}{*}{438} & -3.60 & .00 & .40 \\
& Özel & 78 & 3.54 & .720 & & & & \\
\hline
\end{tabular}


KAHVECi - Çukurova Üniversitesi Eğitim Fakültesi Dergisi, 50(2), 2021, 1069-1099

\begin{tabular}{|c|c|c|c|c|c|c|c|c|}
\hline \multirow{2}{*}{ Dışlama } & Resmi & 362 & 1.95 & .752 & \multirow{2}{*}{438} & \multirow{2}{*}{1.49} & \multirow{2}{*}{.13} & \multirow{2}{*}{.18} \\
\hline & Özel & 78 & 1.82 & .647 & & & & \\
\hline \multirow{2}{*}{ Rekabetçilik Toplam } & Resmi & 362 & 2.80 & .665 & \multirow{2}{*}{438} & \multirow{2}{*}{-2.20} & \multirow{2}{*}{.02} & \multirow{2}{*}{.29} \\
\hline & Özel & 78 & 2.98 & .554 & & & & \\
\hline
\end{tabular}

$* p<0,05$

Kurum türü değişkenine göre rekabetçilik toplam puanı $(t=2.20, p=.02)$ ile onaylanma ve üstünlük puanlarında özel okul öğretmenleri lehine anlamlı fark bulunmaktadır. Etki büyüklüğü rekabetçilik toplam puanında $(d=.29)$ orta, onaylanma puanında $(d=.48)$ orta ve üstünlük puanında $(d=.40)$ orta düzey olarak bulunmuştur.

Öğretmenlerin rekabetçilik puanlarının sahip oldukları eğitim inançları puanları arasındaki korelasyon düzeyi ve korelasyonun yönünü belirlemek için korelasyon analizi yapılmıştır. Korelasyon analizi yapılmadan önce anket formunun eğitim inanları ölçeği bölümünde eksik ve yanlış doldurmuş olan 5 kişinin verileri çıkartılmış ve 435 kişi ile analiz yapılmıştır. Yapılan analiz sonuçları ve betimsel istatistikler Tablo 6'da gösterilmiştir.

Tablo 6.

Öğretmenlerin Rekabetçilik ve Eğitim Inançlarıyla Arasındaki Korelasyon Katsayıları ve Betimsel İstatistik Bulguları

\begin{tabular}{|c|c|c|c|c|c|c|}
\hline Değişkenler & 1 & 2 & 3 & 4 & 5 & 6 \\
\hline 1. Rekabetçilik & - & & & & & \\
\hline 2. Ilerlemecilik & .011 & - & & & & \\
\hline 3. Varoluşçu Eğitim & $-.157 * *$ & $.763 * * *$ & - & & & \\
\hline 4. Yeniden Kurmacılık & .091 & $.553^{* * *}$ & $.495^{* * *}$ & - & & \\
\hline 5. Daimicilik & $.112 * *$ & $.549 * * *$ & $.478 * * *$ & $.593 * * *$ & - & \\
\hline 6. Esasicilik & $.304 * *$ & $-.165^{* *}$ & $-.254 * * *$ & .048 & $.200 * * *$ & - \\
\hline Ortalama & 2.82 & 4.29 & 4.55 & 3.97 & 3.99 & 2.60 \\
\hline Ss & .64 & .42 & .44 & .57 & .50 & .71 \\
\hline Çarpıklık & -0.12 & -0.57 & -.99 & -0.50 & -0.36 & 0.15 \\
\hline Basıklık & 0.70 & 0.21 & 0.70 & -0.58 & -0.31 & -0.01 \\
\hline
\end{tabular}

$* \mathrm{p}<.05, * * \mathrm{p}<.01, * * * \mathrm{p}<.001$

Elde edilen betimsel istatistiklere göre eğitim inançlarının alt boyutları ile rekabetçilik tutumunu gösteren tüm değişkenler normal dağılmaktadır. Ortalama puanlar incelendiğinde öğretmenlerin rekabetçilik tutumları ( $\bar{x}=2.82$ ) orta, eğitim inançlarından ilerlemecilik $(\bar{x}=4.29)$ çok yüksek, varoluşçu eğitim ( $\bar{x}=4.55$ ) çok yüksek, yeniden kurmacılık ( $\bar{x}=3.97)$ yüksek, daimicilik ( $\bar{x}=3.99$ ) yüksek ve esasicilik $(\bar{x}=2.60)$ düşük düzey puan aralığına sahiptir. Korelasyon analizine göre öğretmenlerin rekabetçilik tutumları ile varoluşçu eğitim arasında negatif, daimicilik ve esasicilik puanları arasında pozitif ilişki bulunurken diğer değişkenler ile aralarındaki korelasyon katsayısı anlamsız bulunmuştur. Korelasyon katsayıları bulgusu elde edildikten sonra rekabetçilik tutumlarının eğitim inançları tarafından yordama düzeylerinin belirlenmesi için çoklu regresyon analizi yapılmıştır. Analiz sonuçları Tablo 7'de gösterilmiştir. 
KAHVECi - Çukurova Üniversitesi Eğitim Fakültesi Dergisi, 50(2), 2021, 1069-1099

Tablo 7.

Rekabetçiliğin Eğitim Inançları Tarafından Yordanma Gücünün Belirlenmesine ilişkin Çoklu Regresyon Analizi Sonuçları

\begin{tabular}{|c|c|c|c|c|c|c|c|c|c|c|}
\hline $\begin{array}{l}\text { Yordayıcı } \\
\text { değişkenler }\end{array}$ & B & $\begin{array}{l}\text { Std. } \\
\text { Hata }\end{array}$ & $\begin{array}{l}\text { Beta } \\
(\beta)\end{array}$ & $\mathbf{t}$ & $\mathbf{p}$ & $R$ & $R^{2}$ & $\Delta R 2$ & $\boldsymbol{F}$ & $\mathbf{p}$ \\
\hline (Sabit) & 2.656 & .361 & & 7.35 & .000 & .337 & .113 & .107 & 18.38 & .000 \\
\hline Varoluşçu Eğitim & -.247 & .083 & -.168 & -2.97 & .003 & & & & & \\
\hline Daimicilik & .188 & .071 & .146 & 2.62 & .009 & & & & & \\
\hline Esasicilik & .212 & .046 & .232 & 4.58 & .000 & & & & & \\
\hline
\end{tabular}

$* * p<.01$

Öğretmenlerin rekabetçi tutumlarıyla korelasyon katsayılarından anlamlı olan varoluşçu eğitim, esasicilik ve daimicilik bağımsız değişken olarak çoklu regresyon analizi kapsamına alınmış, ilerlemecilik ve yeniden kurmacılık ise anlamlı bir korelasyona sahip olmadığı için analize alınmamıştır. Yapılan analize göre tolerans ve VIF değerlerinin önerilen aralıkta olduğu, oto korelasyon ve çoklu doğrusal bağlantı sorununun olmadığı tespit edilmiştir. Bu bulgulara göre regresyon sonuçlarının anlamlı olduğu tespit edilmiştir $\left(F_{(3,435)}=18.38, p=.000, R^{2}=.12\right)$. Bu sonuçlara göre öğretmenlerin varoluşçu eğitim inançları rekabetçilik tutumlarını negatif yordarken, daimicilik ve esasicilik inançları pozitif yönde yordamaktadır. Bütün değişkenler öğretmenlerin rekabetçilik tutumlarının \%10.7'sini açıklamaktadır. Elde edilen sonuçlara göre öğretmenlerin rekabetçilik tutumları sırasıyla varoluşçu eğitim inancı tarafından negatif yönde, esasicilik ve daimicilik inançları da pozitif yönde yordamaktadır.

\section{Sonuç ve Tartışma}

Öğretmenlerin cinsiyet değişkenine göre rekabetçilik ve alt boyutlarına ait puanları arasında fark olup olmadığına dair yapılan analizde yarışarak kazanma alt boyutunda erkeklerin kadınlara göre anlamlı düzeyde ve etki büyüklüğü olarak da orta düzeyde yüksek puana sahip oldukları görülmüştür. Hibbard ve Buhrmester (2010) erkeklerin kazanç odaklı yarışma konusunda kadınlardan daha yüksek puana sahip olduğunu bulmuştur. Ayrıca her iki cinsiyet değişkenine ait dışlama alt boyutuna ait puanlar düşük olmakla birlikte erkeklerin puanı kadınlara göre daha yüksektir. Bu farkın etki büyüklüğü de orta düzeydir. Öte yandan rekabetçilik toplam puanları da erkekler lehine anlamlı ve orta derecede etki büyüklüğü ile yüksek bulunmuştur. Bu bulgular Gill (1986) ve Cassidy’nin (2008) bulgularıyla paraleldir. Erkeklerin kadınlara göre daha rekabetçi olması, başarısız olmayı dışlaması ve kazanmaya odaklı yarışmayı daha çok benimsemesi erkeklerin başarı, kazanç ve maddiyat odaklı ilerlemeyi daha çok benimsediğini göstermektedir (Palmer ve Bejau, 1995). Ayrıca erkeklerin başarısızlığı dışlayarak kazanç odaklı rekabetçiliği önemsemesi Hibbard ve Buhrmester'a (2010) göre sosyal çevresindeki kişilerle daha çok fikir ayrılığı içinde olması ve zayıf empati duygusuyla ilişkili olabilir. Diğer yandan erkeklerin geleneksel ataerkil rolleri nedeniyle daha güçlü olmaya odaklanması ve kazanarak hayatta kalma güdüsüyle hareket etmesi bu bulgunun ortaya çıkmasında bir başka etken olabilir.

Okul tipi değişkeni bakımından onaylanma ve üstünlük alt boyutları ile rekabetçilik toplam puanlarında özel okul öğretmenleri lehine anlamlı ve orta düzeyde etki büyüklüğünde fark bulunmaktadır. Bu bulgu çalışılan kurumların çalışma ilkeleri ve koşullarıyla ilişkili olabilir. Titrek ve Zafer (2009) özel okul müdürlerinin resmi okul müdürlerine göre örgütsel güç kaynaklarını daha yüksek düzeyde kullandıklarını belirlemişlerdir. Yasal, zorlayıcı ve ödüllendirme gücünün özel okullarda daha yüksek düzeyde kullanılması özel okul öğretmenlerinin dış otoriteler tarafından onaylanmaya daha fazla ihtiyaç duymasıyla sonuçlanmış olabilir. Seçkin, Danışman ve Babacan (2014, s. 77) özellikle sözleşme dönemlerinde öğretmenlerin birbirleriyle ciddi bir rekabete girdiklerini, velilerin ve yöneticilerin onayını almak için çabaladıklarını belirtmektedir. Taşdan ve Tiryaki (2010) özel okul öğretmenlerinin iş doyumunun gelişme ve yükselme fırsatı boyutunda daha yüksek puana sahip olduğu bulgusuna 
ulaşmıştır. Özel okul öğretmenlerinin gelişme ve yükselme fırsatı konusunda yüksek doyum sahibi olması bu fırsatı değerlendirmek için daha fazla rekabetçi tutum sergilemelerine neden olmuş olabilir.

Öğretmenlerin eğitim inançlarının rekabetçi tutumlarını yordama düzeyinin belirlenmesi amacıyla yapılmış olan çoklu regresyon analizi sonucuna göre eğitim inançlarından varoluşçuluk rekabetçiliği negatif yönde yordamaktadır. Bu bulguya göre varoluşçu eğitim inancı güçlendikçe rekabetçi tutum azalmaktadır. Varoluş̧̧uluk bireyi ve bireyin özgürlüğünü merkeze almaktadır. Gül'e (2014) göre varoluş̧uluk farkı felsefe akımları gibi belirli bir çerçeve içinde tanımlanabilecek bir düşünce değildir. Varoluş̧̧uluk insanın varoluş anlamını ve kendini gerçekleştirme olanaklarını konu edinmekte ve toplumsal düzen ile faydayı ilgi alanının dışında tutmaktadır. Tunca, Alkan-Şahin ve Oğuz (2015)) varoluş̧̧ eğitim inancına sahip olma düzeyinin mesleki değer olarak işbirliğine açık olma, şiddete karşı olma ve farklılıklara saygı duyma değişkenleriyle pozitif yönde bir ilişki olduğu belirtilmiştir. Bu bulgu, rekabetçiliğin iş birliğini dışlayan ve başarısızlığı cezalandıran özellikleri göz önüne alındığında varoluşçu eğitim inancıyla rekabetçilik tutumunun negatif ilişkisini açıklar niteliktedir. Varoluşçuluğun öznelliğe yaptığı güçlü vurgu eşitsizliğin ve statükonun devamını sağladığı iddia edilen eğitim anlayışlarına ve rekabetçiliğe de bir tepkiyi beraberinde getirmektedir. Kozikoğlu ve Erden'in (2018) yaptığı çalışmada varoluş̧̧u eğitim felsefesi ile eleştirel pedagoji ilkelerini benimseme düzeyi arasında düşük de olsa pozitif yönlü bir ilişki olduğu bulgusuna ulaşılmıştır. Eleştirel pedagoji anlayışına göre mevcut eğitim düzeni baskıcıdır. Adaletsizlik üzerine inşa edilmiş ve kapitalist üretim biçimleri tarafından şekillendirilmiştir. Buna karşın eğitim bireyin özgürleşmesine, eleştirel bir bilinç kazanmasına ve adaletin sağlanmasına hizmet etmelidir (Cevizci, 2012, ss. 203-13). Gutek'e (2011, s. 142) göre varoluş̧̧u eğitim düşüncesi bireyin yaşamı kendi açıından değerlendirebileceği, deneyimlerine ve tercihlerine dayalı bir öğretim programını savunmaktadır. Varoluşçulara göre en iyi öğrenme öğrencinin kendi seçtiği ve anlamlandırdığı bilgilere dayalı olan öğrenmedir. Bu durumda mevcut eğitim sistemi ve müfredat varoluş̧̧u anlayışa göre bireyin özgürlüğünü ve öznelliğini önemsemeyen bir yapıdadır. Öğretmenlerin varoluş̧u bakışla mevcut sistemi sorgulamaları, eleştirmeleri ve rekabetçiliğe mesafeli durmaları sahip oldukları eğitim inançlarıyla ilişkili görülebilir.

Öğretmenlerin eğitim inançlarından esasicilik ve daimicilik rekabetçilik tutumlarını sırasıyla pozitif yönde yordamaktadır. Esasicilik felsefi olarak realizm ve idealizmden beslenen bir kuram olup çağdaş eğitim kuramlarıyla çatışmaktadır. Diğer yandan esasicilik toplumsal ve ekonomik değerleri artırabilme potansiyeli olan bilgi ve değerlere önem vermesi nedeniyle liberal düşünceyle benzeşmektedir. Esasiciliğin akademik başarı ve bilgi öğrenme odaklı olması, öğretmen merkezli bir anlayışı savunması (Gutek, 2011, ss. 301-303; Cevizci, 2012, ss. 48-54) rekabetçi tutumla pozitif ilişkisini açıklar niteliktedir. Daimici eğitimde insanın doğasının değişmez olduğu varsayımıyla insanların akıl yetilerinin geliştirilmesi, değişmez gerçekliklerin ve evrensel doğruların öğretilmesi amaçlanmaktadır (Gutek, 2011, s. 306: Cevizci, 2012, s. 28). Daimciliğin önemli ölçüde etkilendiği Platon’a göre insanlar doğası gereği eşit değildir ve insanların alacakları eğitim ve toplumdaki konumları da farklı olmalıdır. Her birey sahip olduğu potansiyel ölçüsünde eğitim almalıdır (Noddings, 2017, s. 8). Toplum da tıpkı bir organizma gibi doğal olarak hiyerarşik bir yapıdadır (Williams, 2019, s. 71). Daimiciliği benimseyen öğretmenlerde de hiyerarşik ve eşitsiz bir toplumun doğal olduğu, herkesin toplumda hak ettiği konumda olmasının adaleti sağlayacağı düşüncesi etkili olabilir. Bu durumda da kimin neyi hak ettiğinin belirlenmesinde insanların yaptıkları işte ve eğitim hayatlarında sahip oldukları başarı sıralaması önemli bir ölçüt olarak kabul edilerek rekabetçiliğe daha olumlu bir anlam yüklenmiş olabilir. Kozikoğlu ve Erden (2018) daimicilik ve esasiciliğin eleştirel pedagoji ilkeleriyle düşük ama negatif yönde bir ilişki olduğunu belirlenmiştir. Eleştirel pedagojinin öğrencilerin hiyerarşik olarak sınıflandırılmasına ve liberalizmin rekabetçiliğine karşı çıkması ve bu yönüyle esasicilik ve daimicilikle negatif ilişkide bulunması çalışmamııın bulgularıyla benzerlik taşımaktadır. Tunca v.d (2015) yapmış oldukları çalışmada mesleki değerlerden farklııklara saygılı olma ve iş birliğine açık olma boyutlarıyla esasiciliğin negatif yönlü ilişkisi olduğunu, daimiciliğin de pozitif olmakla birlikte çağdaş eğitim felsefesi inançlarına göre daha düşük düzeyde ilişkiye sahip olduğunu bulmuştur. Rekabetçiliğin iş birliğini dışlayan, farklııılara saygı duymayı göz ardı eden yapısı göz önüne alındığında bu bulgunun bu çalışmayı destekler nitelikte olduğu söylenebilir. Diğer yandan esasicilik ve daimiciliği benimseyen öğretmenlerin öğretim programlarının içeriğindeki bilgileri nesnel 
kabul ederek bilgilerin öğrenilip öğrenilmediğinin belirlenmesinde ölçüt olarak sadece sınav puanları ve derste gösterilen performansı kabul etmesi rekabetçiliğe karşı daha olumlu tutum geliştirmelerine neden olmuş olabilir.

Öğretmenin inançları ve tutumları öğrencilerin yaşantılarını, öğrenme düzeylerini ve toplum içinde nasıl bir birey olacaklarını belirlemede önemli etkenlerden biridir (Yılmaz vd., 2011). Bu nedenle eğitim inançlarının ve bu inançların dayandıkları kuramların eğitim sürecine olan etkilerine öğretmen eğitimlerinde yer verilerek öğretmenlerin benimseyecekleri eğitim kuramlarını her yönüyle tanıması sağlanabilir.

Rekabetin öğrencinin akademik başarısı üzerinde kısa süreli bir motivasyon sağlamakla birlikte uzun vadede kalıcı öğrenmenin gerçekleşmesinde olumsuz etkileri bulunmaktadır (Lam vd., 2004). Ayrıca rekabetçiliğin öğrencilerin duygusal ve sosyal gelişimi ile olumsuz etkileri de bulunmaktadır (Ökmen vd., 2019; Kahveci ve Sever, 2018). Diğer yandan rekabetçiliğin öğretmenler arası etkileşim ve iş birliğinin zedelenmesine de yol açma olasılığı da göz önüne alındığında yapılan çalışmalar ışığında öğretmenlerin ve eğitim yöneticilerinin rekabetçilik konusunda bilgilendirilmesi önerilebilir.

Eğitim inançlarıyla rekabetçilik arasında nedensel ilişkiye dayanan bir çalışmanın bulunmaması ve sadece bir il merkezindeki örneklemle sınırlı olması nedeniyle benzer çalışmalar farklı örneklemler üzerinde nitel veya nicel yöntemlerle tekrarlanabilir. Ayrıca öğretmenlerin rekabetçiliğe ilişkin tutumlarının farklı değişkenlerle ilişkisi üzerine araştırma yapılması önerilebilecek bir başka husustur.

\section{Etik Beyan}

"Yükseköğretim Kurumları Bilimsel Araştırma ve Yayın Etiği Yönergesinde' yer alan tüm kurallara uyulmuş ve yönergenin ikinci bölümünde yer alan "Bilimsel Araştırma ve Yayın Etiğine Aykırı Eylemlerden" hiçbirisi gerçekleştirilmemiştir.

\section{References}

Akbayırlı, Y. ve Aydın, B. (2000). Bir ölçek geliştirme çalışması: Rekabetçi Tutum Ölçeği (RTÖ): geliştirilmesi, güvenirliği ve geçerliliği. M. Ü. Atatürk Eğitim Fakültesi Eğitim Bilimleri Dergisi, 12, 9-24.

Altınkurt, Y., Yılmaz, K. ve Oğuz, A. (2012). ilköğretim ve ortaöğretim okulu öğretmenlerinin eğitim inançları. Ondokuz Mayıs Üniversitesi Eğitim Fakültesi Dergisi, 31(2), 1-19.

Ateş, S., Çetinkaya Özdemir, E. ve Taneri, A. (2019). İstenmeyen öğretmen davranışlarına ilişkin öğretmen adaylarının görüşleri. Bolu Abant Izzet Baysal Üniversitesi Eğitim Fakültesi Dergisi, 19(1), 37-56.

Aydın, B. ve Akbağ, M. (1997). Aşırı rekabetçi tutum ölçeğinin ülkemiz koşullarına uyarlanması. II. Ulusal Eğitim Sempozyumu Bildiri Kitabı (s.198-204). 18-20 Eylül 1996, Marmara Üniversitesi, İstanbul.

Baudrillard, J. (2010). Tüketim toplumu. Ayrıntı.

Büyüköztürk, Ş., Çokluk Ö. ve Köklü N. (2012). Sosyal bilimler için istatistik. Pegem.

Cassidy, S. (2008). Approaches to learning and competitive attitude in students in higher education. The Psychology of Education Review, 32(1), 18-27.

Cevizci, A. (2012). Eğitim felsefesi. Say.

Cevizci, A. (2017). Felsefeye giriş. Say.

Cohen, J. (1988). Statistical power analysis for the behavioral sciences. Lawrence Erlbaum Associates.

Curtis, N. (2015). Idiotizm: Kapitalizm ve hayatın özelleştirilmesi. İletişim. 
KAHVECi - Çukurova Üniversitesi Eğitim Fakültesi Dergisi, 50(2), 2021, 1069-1099

Dardot, P. ve Laval, C. (2012). Dünyanın yeni aklı: neoliberal toplum üzerine deneme. İstanbul Bilgi Üniversitesi.

Dewey, J. (2013). Deneyim ve eğitim. Odtü Yay.

Doğanay, A. (2011). Hizmet öncesi öğretmen eğitiminin öğretmen adaylarının felsefi bakış açılarına etkisi. Eğitim ve Bilim, 36(161), 332-348.

Fabrigar, L. R., Wegener, D. T., MacCallum, R. C., \& Strahan, E. J. (1999). Evaluating the use of exploratory factor analysis in psychological research. Psychological methods, 4(3), 272-299. https://doi.org/10.1037/1082-989X.4.3.272

Foucault, M. (2015). Biyopolitikanın doğuşu. İstanbul Bilgi Üniversitesi.

George, D., \& Mallery, M. (2010). SPSS for Windows step by step: A simple guide and reference, 17.0 update (10a ed.) Pearson.

Gill, D. L. (1986). Competitiveness among females and males in physical activity classes. Sex Roles, 15(56), 233-247.

Gökberk, M. (2012). Felsefe tarihi. Remzi Kitabevi.

Gökyer, N. ve Türkoğlu, İ. (2018). Liselerde görev yapan öğretmenlerin örgütsel destek algıları ile örgütsel sinizm tutumları arasındaki ilişki. Eğitim ve Bilim, 43(196), 317-340. http://dx.doi.org/10.15390/EB.2018.7440

Griffin-Pierson, S.G. (1990). The Competitiveness quastionnaire measure of two components of competitiveness. Measurement and Evaluation in Counseling and Development, 23, 108-115.

Gunzenhauser, M. G. (2003). High-stake testing and the default philosophy of education. Theory into Practice, 42(1), 51-58. https://doi.org/10.1207/s15430421tip4201 7

Gutek, L. G. (2011). Eğitime felsefi ve ideolojik yaklaşımlar. Ütopya.

Gül, F. (2014). Varoluşçu felsefenin Türk düşünce hayatındaki yansımaları. Pamukkale Üniversitesi Sosyal Bilimler Enstitüsü Dergisi, (18), 27-32.

Harvey, D. (2015). Neoliberalizmin kısa tarihi. Sel.

Helmreich, R. L., \& Spence, J. T. (1978). Work and Family Orientation Questionnaire: an objective instrument to assess components of achievement motivation and attitudes toward family and career. JSAS Catalog of Selected Documents in Psychology, 8(35).

Hibbard, D. R., \& Buhrmester, D. (2010). Competitiveness, gender, and adjustment among adolescents. Sex Roles, 63(5-6), 412 424. https://doi.org/10.1007/s11199-010-9809z

Houston, J. M., Farese, D. M., \& La Du, T. J. (1992). Assessing competitiveness: A validation study of the competitiveness index. Personality and Individual Differences, 13(10), 1153-1156. https://doi.org/10.1016/0191-8869(92)90030-S

Hu, L. T., \& Bentler, P. M. (1999). Cutoff criteria for fit indexes in covariance structural analysis: Conventional criteria versus new alternatives. Structural Equation Modeling, 6, 1-55. https://doi.org/10.1080/10705519909540118

Humphreys, B., Johnson, R. T., \& Johnson, D. W. (1982). Effects of cooperative, competitive, and individualistic learning on students' achievement in science class. Journal of Research in Science Teaching, 19(5), 351-356. https://doi.org/10.1002/tea.3660190503

İlgar, L. (2014). Özel okul ve devlet okulunda görev yapmış sınıf öğretmenlerinin sınıf yönetimindeki farklılıklara ilişkin görüşleri: nitel bir çalışma. HAYEF Journal of Education, 11(2), 259-285.

Johnston, J. S. (2019). John Dewey ve eğitimde pragmatizm. R. Bailey, R. Barrow, D. Carr ve C. McCarthy (Ed.), Eğitim felsefesi kılavuzu içinde (s. 96-108). Pegem. 
KAHVECI - Çukurova Üniversitesi Eğitim Fakültesi Dergisi, 50(2), 2021, 1069-1099

Kahveci, H. ve Sever, M. (2018). Öğretmen görüşlerine göre neoliberal bireyciliğin öğrencilere yansıması. Ankara Üniversitesi Eğitim Bilimleri Fakültesi Dergisi, 51(2), 39-67. https://doi.org/10.30964/auebfd.442809

Karaköse, T. ve Kocabaş, ì. (2013). Özel ve devlet okullarında öğretmenlerin beklentilerinin iş doyumu ve motivasyon üzerine etkileri. Eğitimde Kuram ve Uygulama, 2(1), 3-14.

Kline, R. B. (2005). Principles and practice of structural equation modeling. Guilford.

Kocabaş, i. ve Karaköse, T. (2005). Okul müdürlerinin tutum ve davranışlarının öğretmenlerin motivasyonuna etkisi (özel ve devlet okulu örneği). Türk Eğitim Bilimleri Dergisi, 3(1), 79-93.

Kohn, A. (1986). No contest: The case against competition. Houghton Mifflin.

Kozikoğlu, í. ve Erden, R. Z. (2018). Öğretmen adaylarının eğitim felsefesi inançları ile eleştirel pedagojiye ilişkin görüşleri arasındaki ilişkinin incelenmesi. Elementary Education Online, 17(3).

https://doi.org/10.17051/ilkonline.2018.466392

MacCallum, R. C., Browne, M. W., \& Sugawara, H. M. (1996). Power analysis and determination of sample size for covariance structure modeling. Psychological methods, 1(2), 130-149.

Mead, M. (Ed.). (1937). Cooperation and competition among primitive peoples. McGRAW-Hill.

Moss, G., \& Lee, C. (2010). A critical analysis of philosophies of education and INTASC standards in teacher preparation. International Journal of Critical Pedagogy, 3(2), 36-46.

Neuman W.L. (2007). Toplumsal araştırma yöntemlerinde nitel ve nicel yaklaşımlar. Yayın Odası.

Noddings, N. (2017). Eğitim felsefesi. Nobel.

Nunnally, J. C., \& Bernstein, I. H. (1994). Psychometric theory (3rd ed.). McGrawHill.

Oğuz, M. C. (2017). ABD'de progressivism hareketi ve Woodrow Wilson'un Kurucu Babalar'a itirazı. Amme Idaresi Dergisi, 50(1), 1-25.

Ökmen, B., Şahin, Ş., Boyacı, Z. ve Kılıç, A. (2019). Rekabete dayalı eğitim anlayışı bağlamında bilgi yarışmalarına bakış. Eğitimde Kuram ve Uygulama, 15(3), 253-266. https://doi.org/ 0.17244/eku.441169

Palmer, A., \& Bejou, D. (1995). The effects of gender on the development of relationships between clients and financial advisers. International Journal of Bank Marketing, 3(13), 18-27. https://doi.org/10.1108/02652329510082988

Peterson, R. (2000). A meta-analysis of variance accounted for and factor loadings in exploratory factor analysis. Marketing Letters, 11, 261-275.

Philips, D. C. (2019). Eğitim felsefesi nedir? R. Bailey, R. Barrow, D. Carr, \& C. McCarthy (Ed.), Eğitim felsefesi kılavuzu içinde (s. 3-20). Pegem.

Preacher, K. J., \& MacCallum, R. C. (2003). Repairing Tom Swift's electric factor analysis machine. Understanding Statistics: Statistical Issues in Psychology, Education, and the Social Sciences, 2(1), 1343. https://doi.org/10.1207/S15328031US0201 02

$\mathrm{R}$ Core Team (2018). R: A language and environment for statistical computing. R Foundation for Statistical Computing.

Rosseel, Y. (2012). Lavaan: An R package for structural equation modeling and more. Version 0.5-12 (BETA). Journal of Statistical Software, 48(2), 1-36. https://www.jstatsoft.org/article/view/v048i02

Qin, Z., Johnson, D. W., \& Johnson, R. T. (1995). Cooperative versus competitive efforts and problem solving. Review of Educational Research, 65(2), 129. https://doi.org/10.3102/00346543065002129

Riskind. J. H. \& Wilson D. W (1982). Interpersonal attraction for the competitive person: unscrambling the competition paradox. Journal of Applied Social Psychology, 12(6), 444-452. https://doi.org/10.1111/j.1559-1816.1982.tb00878.x 
KAHVECi - Çukurova Üniversitesi Eğitim Fakültesi Dergisi, 50(2), 2021, 1069-1099

Schreiber, J. B., Nora, A., Stage, F. K., Barlow, E. A., \& King, J. (2006). Reporting structural equation modeling and confirmatory factor analysis results: A review. The Journal of educational research, 99(6), 323-338. https://doi.org/10.3200/JOER.99.6.323-338

Seçkin M., Danışman Ş. ve Babacan T. (2014). Parayı veren düdüğü çalar, derhsane öğretmenlerinin deneyimleri A. Aypay ve M. Sever (Ed.) Öğretmenlik Halleri: Türkiye'de öğretmen olmak üzerine bir araştırma içinde (s. 49-90). Pegem.

Simmons, C. H., King, C. S., Tucker, S. S., \& Wehner, E. A. (1986). Success strategies: Winning through cooperation or competition. The Journal of Social Psychology, 126(4), 437-444. https://doi.org/10.1080/00224545.1986.9713610

Smither, R. D., \& Houston, J. M. (1992). The nature of competitiveness: The development and validation of the competitiveness index. Educational and Psychological Measurement, 52(2), 407-418. https://doi.org/10.1177/0013164492052002016

Tabachnick, B. G., \& Fidell, L. S. (2007). Using multivariate statistics (5th ed.). Allyn \& Bacon/Pearson Education.

Taşdan, M. ve Tiryaki, E. (2010). Özel ve devlet ilköğretim okulu öğretmenlerinin iş doyumu düzeylerinin karşılaştırılması. Eğitim ve Bilim, 33(147), 54-70.

Tauer, J. M., \& Harackiewicz, J. M. (1999). Winning isn't everything: Competition, Achievement orientation, and intrinsic motivation. Journal of Experimental Social Psychology, 35(3), 209-238. https://doi.org/10.1006/jesp.1999.1383

Titrek, O. ve Zafer, D. (2009). İlköğretim okulu yöneticilerinin kullandıkları örgütsel güç kaynaklarına ilişkin öğretmen görüşleri. Kuram ve Uygulamada Eğitim Yönetimi, 60(60), 657-674.

Thornton, B., Ryckman, R., \& Gold, J. (2011). Competitive orientations and the type A behavior pattern. Psychology, 2, 411-415. https://doi.org/10.4236/psych.2011.25064.

Tsiakara, A., \& Digelidis, N. M. (2014). Assessing preschool children's competitive behaviour: an observational system. Early Child Development and Care, 184(11), 1648-1660. https://doi.org/10.1080/03004430.2013.873035

Tunca, N., Alkın-Şahin, S. ve Oğuz, A. (2015). Öğretmenlerin eğitim inançları ile meslekî değerleri arasındaki ilişki. Kalem Eğitim ve Insan Bilimleri Dergisi, 5(1), 11-47.

Ünder, H. (1993). Platon'un devletinde eğitim ve insan doğası. Ankara Üniversitesi Eğitim Bilimleri Fakültesi Dergisi, 26(1), 185-201.

Williams, I. (2019). Platon ve eğitim. R. Bailey, R. Barrow, D. Carr ve C. McCarthy (Ed.), Eğitim felsefesi kılavuzu içinde (s. 67-81), Pegem.

Worthington, R. L., \& Whittaker, T. A. (2006). Scale development research: A content analysis and recommendations for best practices. The Counseling Psychologist, 34(6), 806-838. https://doi.org/10.1177/0011000006288127

Yılmaz, K., Altınkurt, Y. ve Çokluk, Ö. (2011). Eğitim inançları ölçeğinin geliştirilmesi: Geçerlik ve güvenirlik çalışması. Kuram ve Uygulamada Eğitim Bilimleri, 11(1), 335-350. 


\section{Appendix: Teacher Competitiveness Scale}

WINNING BY COMPETITION

1- The most important criterion for success is passing the competitors.

2- Whatever the circumstances are, winning is better than losing.

3- Life is a race.

4- All rewards at school should be based on academic achievement. APPROVAL

1- I would like to be rewarded for my successful works.

2- I care that the managers appreciate me.

3- I want to be a teacher appreciated by parents.

4- I would like the successful teachers to be rewarded.

\section{SUPERIORITY}

1- I aim to do what is better than anyone else.

2- I struggle to be the most successful teacher in school.

3- Having competitors while doing a job motivates me.

4- I struggle to be the best person who does a work.

\section{EXCLUSION}

1- I prefer to spend more time with successful students.

2- I give more importance to successful students.

3- I welcome negative behaviors of successful students more tolerantly.

4- Caring for unsuccessful students is a waste of time.

\section{Ek: Öğretmenlerde Rekabetçilik Ölçeği}

YARIŞARAK KAZANMA

1- Başarının en önemli ölçütü rakipleri geçmektir.

2- Koşullar ne olursa olsun, kazanmak kaybetmekten iyidir.

3- Hayat bir yarıştır.

4- Okulda tüm ödüllendirmeler akademik başarıya göre olmalıdır.

\section{ONAYLANMA}

1- Başarılı olduğum işlerde ödüllendirilmek isterim.

2- Yöneticilerin beni takdir etmesini önemserim.

3- Veliler tarafından takdir edilen öğretmen olmak isterim.

4- Başarılı öğretmenlerin ödüllendirilmesini isterim.

ÜSTÜNLÜK KURMA

1- Herkesten daha iyi olanı yapmayı hedeflerim.

2- Okulda en başarılı öğretmen olmak için çabalarım.

3- Bir işi yaparken rakiplerimin olması beni motive eder.

4- Bir işi en iyi yapan kişi olmak için çabalarım.

\section{DIŞLAMA}

1- Başarılı öğrencilere daha çok zaman ayırmayı tercih ederim.

2- Başarılı öğrencilere daha fazla değer veririm.

3- Başarılı öğrencilerin olumsuz davranışlarını daha hoşgörülü karşılarım.

4- Başarısız öğrencilerle ilgilenmek zaman kaybıdır. 